\title{
4
}

\section{Mouse Models of Hepatocellular Carcinoma}

\author{
Rodrigo Carlessi ${ }^{1} \bullet$ Julia Köhn-Gaone ${ }^{1}$ John K. Olynyk ${ }^{2,3} \bullet$ \\ Janina E. E. Tirnitz-Parker ${ }^{1,4}$ \\ ${ }^{1}$ School of Pharmacy and Biomedical Sciences, Curtin Health Innovation Research \\ Institute, Bentley, WA, Australia; ${ }^{2}$ Fiona Stanley and Fremantle Hospitals, Fremantle and \\ Murdoch, WA, Australia; ${ }^{3}$ School of Health and Medical Sciences, Edith Cowan University, \\ Joondalup, WA, Australia; ${ }^{4}$ Centre for Cell Therapy and Regenerative Medicine, School of \\ Biomedical Sciences, The University of Western Australia, Crawley WA, Australia
}

Authors for correspondence: Rodrigo Carlessi, School of Pharmacy and Biomedical Sciences, Curtin Health Innovation Research Institute, Bentley, WA, Australia. Email: rodrigo.carlessi@curtin.edu.au; Janina E. E. Tirnitz-Parker, School of Pharmacy and Biomedical Sciences, Curtin Health Innovation Research Institute, Bentley, WA, Australia. Email: n.tirnitz-parker@curtin.edu.au

Doi: http://dx.doi.org/10.15586/hepatocellularcarcinoma.2019.ch4

\begin{abstract}
Hepatocellular carcinoma (HCC) represents a major and steadily increasing global health challenge as the most common primary liver malignancy and leading cause of death in cirrhotic patients. The only hope for curative treatment or significant increase in life expectancy is early detection. Once patients have progressed towards end-stage HCC, effective treatment options are extremely limited on the background of a very high degree of heterogeneity in clinical presentation and outcome. Experimental chronic liver injury and cancer have been used extensively to mimic the human disease. In particular, mouse studies have advanced the field due to the ability to easily manipulate the mouse genome and transcriptome for mechanistic evaluations. In addition, they offer the opportunity to screen new therapeutic strategies cost-effectively
\end{abstract}

In: Hepatocellular Carcinoma. Janina E.E. Tirnitz-Parker (Editor), Codon Publications, Brisbane, Australia. ISBN: 978-0-9944381-8-8. 2019; Doi: http://dx.doi.org/10.15586/ hepatocellularcarcinoma.2019

Copyright: The Authors.

License: This open access article is licensed under Creative Commons Attribution 4.0 International (CC BY 4.0). https://creativecommons.org/licenses/by-nc/4.0/ 
and in quick high-throughput, large-scale formats. The most commonly used mouse models in HCC research can be categorized as chemotoxic, diet-induced, and genetically engineered models. It is important to note that no particular model mimics all features of a given HCC etiology or histological subtype, and each model poses advantages and disadvantages that need to be carefully considered.

Keywords: cirrhosis; hepatocellular carcinoma; hydrodynamic tail vein injection; non-alcoholic fatty liver disease; non-alcoholic steatohepatitis.

\section{INTRODUCTION}

Liver cancer is the seventh most common cancer worldwide, and one of the deadliest, with a 5-year survival rate in the range of 5-30\% (1). A recent assessment by the Global Burden of Disease Cancer Collaboration revealed that 1 in 38 men and 1 in 111 women will develop liver cancer at some point in their lives (2). In 2016, liver cancer contributed to approximately $10 \%$ of all cancerrelated deaths worldwide, ranking second in terms of the absolute number of years of life lost, only behind lung cancer (2). High morbidity and mortality rates underscore the need to develop platforms to identify diagnostic tools for better and earlier detection and more effective targeted therapies, in order to halt disease progression and improve survival of patients. Therefore, appropriate preclinical models of liver cancer, in particular hepatocellular carcinoma (HCC) - the most common type of liver cancer, representing approximately $70 \%$ of all primary liver malignancies $(3,4)$-are critical research tools that enable breakthroughs in the biology of hepatocarcinogenesis and testing of novel therapies. Current therapy options for HCC are limited to surgical and non-surgical ablative therapies or liver transplantation; systemic approaches, such as treatments with multikinase inhibitors, only prolong the life expectancy of patients by $2-3$ months (5).

Human hepatocarcinogenesis typically occurs secondary to chronic liver diseases. These include the iron overload disorder hemochromatosis, viral hepatitis, alcoholic fatty liver disease (AFLD), and non-alcoholic fatty liver disease (NAFLD), all of which can promote steatosis, the build-up of excess fat in liver cells, and steatohepatitis, when the condition is accompanied by inflammatory and fibrogenic components. Steatohepatitis causes cellular damage and oxidative stress and instigates the release of pro-inflammatory and pro-fibrogenic signaling molecules, which (i) recruit immune cells to the site of injury, (ii) induce hepatic stellate cell-mediated collagen deposition in the hepatic wound healing response, and (iii) activate liver progenitor cells, as part of a socalled Ductular reaction, to replace lost tissue $(6,7)$. If injury is halted, matrix is resorbed and normal liver architecture is restored. However, chronic pathological insults can lead to excessive fibrosis, cirrhosis, and ultimately liver cancer (Figure 1) (7).

Micehave become the pillar for biomolecular discovery in human disease due to numerous advantages over other model organisms $(8,9)$. An ever-growing list of mouse models has been developed to study different aspects of chronic liver 
Stages of liver damage and progression to HCC

Potentially reversible if injury is halted or with treatment
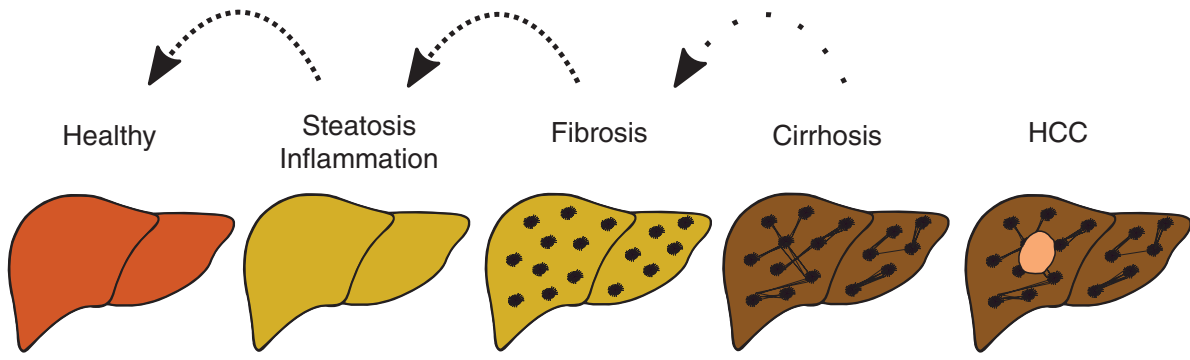

CHRONIC LIVER DISEASE

(such as viral hepatitis, alcoholic and

non-alcoholic fatty liver disease, haemochromatosis)

Figure 1 Progressive stages of liver disease to hepatocellular carcinoma development. Chronic liver diseases that predispose to hepatocellular carcinoma (HCC) are generally characterized by steatosis and hepatocellular damage or death, followed by inflammation and fibrosis. These are initial and potentially reversible wound healing when the disease stimulus is withdrawn. However, if the injury is persistent, liver disease may progress to end-stage complications such as cirrhosis and HCC.

disease and progression to HCC. However, appropriate recapitulation of human pathological features has been challenging. Furthermore, when analyzed in detail, distinct models have been shown to induce remarkably different pathological patterns (10). This chapter describes some commonly used as well as the most recently developed mouse models of HCC. Table 1 indicates the timeframe for HCC development and highlights some of the most prominent features and characteristics of each model discussed in this chapter (Table 1).

A variety of strategies can be used to generate HCC in mice. These involve administration of toxic agents, genetic modifications such as expression of oncogenes or disruption of tumor suppressor genes, cancer-promoting diets, and xenograft implantation models. Often, multiple strategies are combined in order to achieve clinically relevant disease progression to mimic human HCC. Thus, it is important to choose the most appropriate model and time point to best answer an underlying research question. Importantly, it may be necessary to validate novel therapeutic targets across multiple models before they can be considered for translation into clinical trials.

\section{CHEMOTOXIC MODELS}

Several hepatotoxins have been used to induce HCC in mice. These chemicals either cause DNA damage directly and, therefore, produce cancer-promoting mutations, or act indirectly by facilitating clonal expansion of transformed cells (11). Timing and reproducibility of tumor development can vary significantly between different compounds and, interestingly, between studies from 


\begin{tabular}{|c|c|c|c|}
\hline TABLE 1 & \multicolumn{3}{|c|}{$\begin{array}{l}\text { Commonly used mouse models of hepatocellular } \\
\text { carcinoma classified as chemotoxic, diet-based, } \\
\text { and genetic }\end{array}$} \\
\hline Model & $\begin{array}{l}\text { HCC development } \\
\text { (time) }\end{array}$ & Features & References \\
\hline \multicolumn{4}{|l|}{ Chemotoxic } \\
\hline DEN & $\begin{array}{l}\text { Males }>80 \% \text {, } \\
\text { females } 10-30 \% \\
\text { incidence at } \\
9 \text { months. }\end{array}$ & $\begin{array}{l}\text { Neutrophil infiltration, bile duct } \\
\text { proliferation, centrilobular hemorrhagic } \\
\text { necrosis, bridging necrosis. No fibrosis } \\
\text { or cirrhosis. }\end{array}$ & $(15-18,21-27)$ \\
\hline $\mathrm{CCl}_{4}$ & $\begin{array}{l}\text { 1-2 years for most } \\
\text { mice strains. As } \\
\text { early as } 15 \text { weeks } \\
\text { in A/J mice }\end{array}$ & $\begin{array}{l}\text { Hepatocyte necrosis, steatosis, Kupffer cell } \\
\text { activation, immune cell infiltration. } \\
\text { Fibrosis precedes HCC. }\end{array}$ & $(42-52)$ \\
\hline TAA & 6-12 months & $\begin{array}{l}\text { Mild steatosis, centrilobular necrosis, } \\
\text { severe inflammation. Steady progressive } \\
\text { worsening of inflammatory, fibrogenic } \\
\text { and progenitor cell responses. Strong } \\
\text { centrally-driven fibrotic component, } \\
\text { progressing to cirrhosis prior to HCC. }\end{array}$ & $\begin{array}{l}(10,58-61 \\
63-68 \\
71-74)\end{array}$ \\
\hline $\mathrm{DEN}+\mathrm{CCl}_{4}$ & $\begin{array}{l}100 \% \text { incidence at } \\
5 \text { months }\end{array}$ & $\begin{array}{l}\text { Similar to } \mathrm{CCl}_{4} \text { alone but with shortened } \\
\mathrm{HCC} \text { latency and increased presence of } \\
\text { progenitor cells. }\end{array}$ & $(54,55)$ \\
\hline $\mathrm{DEN}+\mathrm{TAA}+\mathrm{HFD}$ & $\begin{array}{l}100 \% \text { incidence at } \\
6 \text { months }\end{array}$ & $\begin{array}{l}\text { Reliable progression to } \mathrm{HCC} \text { with short } \\
\text { latency. Includes steatosis, inflammatory } \\
\text { and fibrogenic features. }\end{array}$ & (75) \\
\hline \multicolumn{4}{|l|}{ Diet } \\
\hline CDE & $\begin{array}{l}75 \% \text { incidence at } \\
14 \text { months }\end{array}$ & $\begin{array}{l}\text { Periportal injury, severe steatosis at early } \\
\text { stages. Mild to moderate fibrosis, strong } \\
\text { liver progenitor cell component. }\end{array}$ & $(10,92,93)$ \\
\hline ALIOS & $\begin{array}{l}60 \% \text { incidence at } \\
1 \text { year }\end{array}$ & $\begin{array}{l}\text { Severe steatosis, hepatic necrosis and } \\
\text { inflammation. Ballooning hepatocytes } \\
\text { and Mallory hyaline at } 16 \text { weeks. Mild } \\
\text { periportal to bridging fibrosis, later liver } \\
\text { progenitor cell involvement. }\end{array}$ & $(97,98)$ \\
\hline DIAMOND & $\begin{array}{l}89 \% \text { incidence at } \\
1 \text { year (can be } \\
\text { accelerated to } \\
6 \text { months by } \\
\text { combination } \\
\text { with } \mathrm{CCl}_{4} \text { ). }\end{array}$ & $\begin{array}{l}\text { Pronounced hepatocyte ballooning and } \\
\text { progressive fibrosis at } 6 \text { months. } \\
\text { Strong histologic and transcriptomic } \\
\text { similarities with human NASH } \\
\text { and HCC. }\end{array}$ & $(99-101)$ \\
\hline
\end{tabular}




\section{TABLE 1 Commonly used mouse models of hepatocellular carcinoma classified as chemotoxic, diet-based, and genetic (Continued)}

\begin{tabular}{|c|c|c|c|}
\hline Model & $\begin{array}{l}\text { HCC development } \\
\text { (time) }\end{array}$ & Features & References \\
\hline MUP-uPA+HFD & $\begin{array}{l}78.6 \% \text { incidence at } \\
32-40 \text { weeks }\end{array}$ & $\begin{array}{l}\text { Several hallmarks of human NASH } \\
\text { (activation of hepatic stellate } \\
\text { cells, bridging fibrosis, immune } \\
\text { cell infiltration, and ballooning } \\
\text { hepatocytes), Highlights the role of ER } \\
\text { stress in HCC development. }\end{array}$ & $(102,103)$ \\
\hline \multicolumn{4}{|l|}{ Genetic } \\
\hline c-Myc & $\begin{array}{l}\text { Incidence of } 40 \% \text { at } \\
45 \text { weeks, } 60 \% \\
\text { at } 55 \text { weeks, and } \\
80 \% \text { at } 65 \text { weeks }\end{array}$ & $\begin{array}{l}\text { Mild to severe hepatic dysplasia at 2-3 } \\
\text { months of age. First carcinogenic } \\
\text { lesions at about } 1 \text { year of age. Can } \\
\text { be accelerated by co-expression of } \\
\text { TGF- } \alpha \text { and prevented by HGF. HCC } \\
\text { development drastically accelerated by } \\
\text { co-treatment with } \mathrm{CCl}_{4} \text {. }\end{array}$ & (109-113) \\
\hline E2F1 & $\begin{array}{l}\text { Incidence of } 33 \% \text { at } \\
1 \text { year }\end{array}$ & $\begin{array}{l}\text { Hepatic dysplasia at } 2 \text { months and } \\
\text { adenomas at } 6 \text { months. HCC } \\
\text { development accelerated by c-Myc } \\
\text { co-expression. }\end{array}$ & $(115,116)$ \\
\hline $\begin{array}{c}\text { Active } \beta \text {-catenin } \\
+\mathrm{H} \text {-ras }{ }^{\mathrm{G} 12 \mathrm{~V}}\end{array}$ & $\begin{array}{l}100 \% \text { incidence } \\
\text { within } 2 \text { months } \\
\text { of genetic } \\
\text { manipulation }\end{array}$ & $\begin{array}{l}\text { Active } \beta \text {-catenin alone does not progress } \\
\text { to HCC. Combination with H-ras }{ }^{\mathrm{G} 12 \mathrm{~V}} \\
\text { induces rapid HCC development. } \\
\text { Dysplastic hepatocytes surrounded by } \\
\text { immune infiltration in the first } 4 \text { weeks } \\
\text { and multifocal nodules by } 5 \text { weeks. }\end{array}$ & $(122,123)$ \\
\hline Apc KO & $\begin{array}{l}67 \% \text { incidence at } \\
8-9 \text { months }\end{array}$ & $\begin{array}{l}\text { Dose of adenoviral injections is key } \\
\left(0.5 \times 10^{9} \mathrm{pfu}\right) \text {. High doses increase } \\
\text { mortality risk. Trabecular and well- } \\
\text { differentiated HCCs. }\end{array}$ & $(124,125)$ \\
\hline $\operatorname{Trp} 53 \mathrm{KO}$ & $14-20$ months & $\begin{array}{l}\text { Majority of tumors display bipotential } \\
\text { cell phenotypes (co-expression of } \\
\text { hepatocyte and biliary markers). }\end{array}$ & $(127,129)$ \\
\hline PTEN KO & $\begin{array}{l}\text { Incidence of } 47 \% \\
\text { at } 44 \text { weeks and } \\
66 \% \text { at } 74-78 \\
\text { weeks }\end{array}$ & $\begin{array}{l}\text { Hepatomegaly and steatosis at } 10 \\
\text { weeks. Features of NASH (hepatic } \\
\text { inflammation and fibrosis) at } 40 \text { weeks. }\end{array}$ & $(132,133)$ \\
\hline
\end{tabular}

Active $\beta$-catenin, $\beta$-catenin gene Ctnnbl lacking exon 3; ALIOS, American lifestyle-induced obesity syndrome; Apc, adenomatous polyposis coli; $\mathrm{CCl}_{4}$, carbon tetrachloride; $\mathrm{CDE}$, choline-deficient and ethionine-supplemented diet; c-Myc, Myc proto-oncogene; DEN, diethylnitrosamine; DIAMOND, diet-induced animal model of non-alcoholic fatty liver disease; E2F1, E2F transcription factor 1; HFD, high-fat-diet; H-rasG12V, substitution of glycine with valine at position 12 of human RAS; MUP-uPA, major urinary protein-urokinase-type plasminogen activator transgenic mice; PTEN KO, liver-specific knockout of phosphatase and tensin homolog; TAA, thioacetamide; Trp53 KO, liver-specific knockout of the mouse p53 ortholog. 
different research groups. The latter possibly reflects differences in the murine gut microbiota, which are known to play key roles in tumor growth, as recently demonstrated in pancreatic and colon cancer as well as melanoma (12). Hepatotoxins that are generally regarded as appropriate tumor inducers mostly recapitulate the multistep progression stages of human HCC involving injury, steatosis, inflammation, fibrosis, and carcinogenesis. However, the degree and level of interplay of these histological changes often varies. The most commonly used hepatotoxins to study HCC in mice are discussed below.

\section{Diethylnitrosamine (DEN)}

DEN, also known as $N$-nitrosodiethylamine, is probably the most commonly used chemical to induce liver cancer in mice and is either administered orally or through peritoneal injection. DEN is bioactivated in centrilobular hepatocytes in a cytochrome P450-dependent manner and produces metabolic sub-products that have DNA alkylating properties, ultimately leading to mutagenesis (13). Tumor incidence is reduced in CYP2 El-deficient compared to wild-type mice, suggesting that it may be one of the key CYP enzymes that catalyzes DEN bioactivation (13). DEN administration also induces reactive oxygen species (ROS) formation and oxidative stress, which constitutes an additional mechanism by which it promotes hepatocarcinogenesis (14).

A single intraperitoneal dose of $5 \mathrm{mg} / \mathrm{kg}$ of DEN to weaning, 15-days-old male mice is sufficient to induce hepatocarcinogenesis in approximately $80 \%$ of all animals 9 months after induction (15). However, long-term administration or higher doses of DEN can reach an incidence of $100 \%$ in shorter timeframes (15-18). While DEN reliably induces HCC, dose, timing of administration, gender, age, and strain impact the severity and timing of tumor appearance (19). High cellular proliferation is known to enhance mutagenesis by chemical carcinogens both in vitro and in vivo (20). Thus, in most cases, juvenile mice are used, which display actively proliferating hepatocytes at this stage of their development. DEN treatment results in the expansion of cells with oncogenic mutations, leading to dysplastic lesions that eventually give rise to carcinomas (19).

Vesselinovitch and Mihailovich conducted an extensive dose-time response kinetics study of DEN-induced hepatic carcinogenesis, which included evaluation of early alterations such as basophilic foci and nodules, as well as late transformation to adenomas and hepatocellular carcinoma lesions (21). Briefly, HCC developed more reliably when DEN was administrated to younger mice (15-days old) in a dose-dependent manner, ranging from as little as 0.625 up to $5 \mathrm{mg} / \mathrm{kg}$ of body weight, whereas treatment of more mature mice (42-days old) with doses up to $50 \mathrm{mg} / \mathrm{kg}$ failed to induce predictable carcinogenesis within the same observational period of up to 110 weeks (21).

Another factor influencing the carcinogenicity of DEN is the gender. The incidence for DEN-induced liver cancer can reach 100\% for male mice, but is only approximately $10-30 \%$ in females, indicating a gender-specific differential response (22-27). Nakatani et al. studied the influence of hormonal factors and demonstrated that ovariectomy or testosterone supplementation increased the occurrence of liver tumors in females treated with DEN. Furthermore, male castration paralleled by estrogen administration resulted in a reduced tumor incidence of $26 \%$, similar to the prevalence observed in females (28). 
These findings in experimental liver carcinogenesis are consistent with the observation that men are three to five times more likely to develop HCC than women (29). The precise molecular mechanisms underlying gender imbalance are not completely understood, but have recently been demonstrated to involve estrogen-dependent interleukin (IL)-6 inhibition in females, and direct downstream effects in nuclear factor kappa B (NF- $\mathrm{KB}$ ) and signal transducer and activator of transcription 3 (STAT3) signaling, two key transcription factors in HCC development $(24,30)$.

The sequence of hepatic alterations in DEN-treated mice is highly similar to human chronic liver disease to HCC progression. During the course of their life, mice subjected to DEN develop histological alterations that include neutrophil infiltration, bile duct proliferation, centrilobular hemorrhagic necrosis, and bridging necrosis, all of which are observed in human HCC (31). However, the most common histopathological features of human HCC, fibrosis, and cirrhosis (32) are not observed with DEN administration alone (33). Indeed, $80-85 \%$ of all cases of HCC occur in cirrhotic patients, and only about $10 \%$ of HCC cases are reported in the absence of any chronic liver disease (34). Thus, models that include fibrogenesis are most relevant to a better understanding of the pathogenesis of human disease. The combination of DEN with fibrotic compounds such as carbon tetrachloride $\left(\mathrm{CCl}_{4}\right)$ and thioacetamide (TAA) has been demonstrated to better model this particular feature of HCC (35).

\section{Carbon tetrachloride $(\mathrm{CCl} 4)$}

$\mathrm{CCl}_{4}$ was widely used as a fumigant, cleaning product, and in fire extinguishers until it was phased out due to safety concerns and banned worldwide in 1996, under the "Montreal Protocol on Substances that Deplete the Ozone Layer." $\mathrm{CCl}_{4}$ is a hepatotoxin known to induce liver damage, infiltration of inflammatory cells, and fibrosis (36). Similar to DEN, hepatotoxicity involves metabolism through cytochrome P450 and generation of toxic metabolic sub-products in hepatocytes $(37,38)$. One of them, trichloromethyl radical $\left(\mathrm{CCl}_{3}{ }^{*}\right)$, is a highly reactive intermediary that can damage nucleic acids, proteins, and lipids, leading to impairments in diverse cellular processes (39). The main mechanism for $\mathrm{CCl}_{4}$-induced hepatic toxicity involves exacerbated lipid peroxidation, which leads to plasma membrane damage and secondary accumulation of lipoproteins and lipid droplets in hepatocytes $(40,41)$. Thus, one advantage of the $\mathrm{CCl}_{4}$ model is that it includes hepatic steatosis in its pathogenesis. Additionally, $\mathrm{CCl}_{4}$ promotes activation of Kupffer cells, and this has been demonstrated to be necessary for its fibrogenic effect (42). Pro-inflammatory signaling mediated by Kupffer cells attracts further immune cell recruitment and infiltration, which contributes to the tissue damage elicited by $\mathrm{CCl}_{4}$ administration (43). A single dose of $\mathrm{CCl}_{4}$ leads to centrilobular liver necrosis, followed by tissue repair and regeneration (44). Thus, in contrast to $\mathrm{DEN}, \mathrm{CCl}_{4}$ must be administrated chronically and/or repeatedly in order to lead to cycles of injury, inflammation, fibrosis, and cirrhosis, and it eventually gives rise to HCC (11).

$\mathrm{CCl}_{4}$ is most often provided to mice as a $2-4 \mathrm{~mL} / \mathrm{kg} 50 \%$ solution in mineral or vegetal oil, either by gavage or intraperitoneally (45-47). However, a significant variation in dosage can be found in the literature. Inhalation exposure has also been utilized, although this route is much less common (48). The frequency 
of doses also varies in different protocols, but generally consists of weekly, biweekly, or three times a week administrations. While the pathology induced by $\mathrm{CCl}_{4}$ has a prominent fibrogenic component $(49,50)$ and $\mathrm{A} / \mathrm{J}$ male mice were shown to present $100 \%$ incidence of HCC following a protocol of only 17 -weeks of $\mathrm{CCl}_{4}$ administration (49), the evolution to HCC generally only occurs after long-term exposures of $1-2$ years for most mouse strains $(11,51,52)$. Therefore, $\mathrm{CCl}_{4}$ is often combined with other tumor-promoting agents such as alcohol, DEN, and others, which allow for a more timely induction of hepatic carcinogenesis, while maintaining the inflammatory and fibrogenic components that are akin to human HCC (53). For example, a single dose of DEN at 2 weeks of age, followed by biweekly administrations of $\mathrm{CCl}_{4}$ led to a two fold increase in carcinogenesis at 5 months of age $(54,55)$. Interestingly, this was associated with significant increase in the expression of progenitor cell markers in the noncancerous parenchyma, suggesting the role of fibrosis in promoting cellular alterations that lead to carcinogenesis. The presence of cells expressing progenitor features has been associated with a more aggressive tumor phenotype and poorer outcomes in human studies $(56,57)$. However, the exact role of progenitor cells in the development of HCC is largely unknown and is a subject of intense research in the field (7).

\section{Thioacetamide (TAA)}

TAA has mostly been used to induce fibrosis, cirrhosis, and liver cancer, including cholangiocarcinoma in rats, but studies increasingly emerge on hepatic TAA toxicity in mice (10., 58-61). TAA is an organosulfur compound that undergoes a two-step bioactivation through the flavin-adenine dinucleotide-containing monooxygenases or cytochrome P450 via TAA sulfoxide (TASO or sulfine) to thioacetamide sulfdioxide (TASO2 or sulfene). TASO2 is a highly reactive metabolite, which causes significant fat deposition, necrosis, and inflammatory cell aggregates in centrilobular areas, where TAA is metabolized $(10,62)$. The mechanisms of toxicity are believed to be secondary to its oxidant properties, including lipid peroxidation and production of ROS, dampening antioxidant defenses and exacerbating hepatic oxidative stress (62). In mice, it is usually administered by the addition of drinking water at 300 to $600 \mathrm{mg} / \mathrm{L}$, allowing for a simple model to induce carcinogenesis without the need for regular injections $(10,60,63)$. However, it can also be administered intraperitoneally two to five times a week (63-65).

A detailed 6-week time course analysis by Köhn-Gaone and colleagues compared the molecular and cellular injury dynamics of TAA-induced chronic liver injury to feeding of a choline-deficient and ethionine-supplemented (CDE) diet in mice (10). While the CDE diet induced periportal injury, steatosis, and fibrosis with a peak of all measured injury parameters in the first 2 weeks, followed by slow normalization of liver histology and function, TAA supplementation led to progressively worsening inflammatory, fibrogenic, and liver progenitor cell responses. Various studies have reported portal, portalportal, or portal-central bridging in the TAA model $(63,66-68)$. However, the comprehensive time course analysis in C57BL/6 mice revealed that fibrosis is centrally driven in TAA liver injury and progresses to cirrhosis within only 6 weeks of treatment (10). Long-term treatment with TAA alone has been 
demonstrated to induce HCC within $14-16$ weeks in rats $(69,70)$. Murine studies are much rarer in the literature and describe HCC development after 26 weeks to 12 months of TAA treatment (71-74). Figure 2 illustrates tumor histology and characteristics of TAA-induced HCC development compared to CDE-mediated HCC development in mice after 7 months of treatment.

Often, TAA has been used in combination with other methods to induce hepatocarcinogenesis in a shorter timeframe. For instance, combination of a single dose of DEN at 14 days, accompanied by $300 \mathrm{mg} / \mathrm{L}$ of TAA in the drinking water, along with high-fat-diet (HFD) feeding from 4 weeks of age, elicited histological features of inflammation, steatosis, and fibrosis that were significantly exacerbated as early as 12 weeks of treatment, and $100 \%$ of animals progressed to liver tumors by 24 weeks (75). Such combinatory strategies not only recapitulate different features of human HCC but may also significantly reduce the time for tumor development and have therefore become quite popular in liver cancer research (76).

\section{DIET-INDUCED MODELS}

Recent advances in antiviral therapies, which can result in permanent suppression of hepatitis B virus (HBV) and eradication of $\mathrm{HCV}$, are significantly reducing the incidence of HCC from viral etiology (77). Furthermore, the second and most prevalent risk factor for HCC, alcoholic steatosis, is relatively stable over time (78). This can be attributed to observations pointing to steady or decreasing trend of alcohol consumption per capita in most countries over the past decades (79). Therefore, NAFLD and its advanced form, non-alcoholic steatohepatitis (NASH), are responsible for the current and future increases in chronic liver disease and HCC incidence worldwide (80). NAFLD is the hepatic manifestation of the metabolic syndrome and is estimated to affect an astonishing $24 \%$ of the world population (81). NAFLD is generally accompanied by obesity, insulin resistance, and dyslipidemia. Thus, diet-induced models that manifest those metabolic alterations are well suited to represent human NAFLD-driven HCC. Noteworthy, only a small fraction of patients with NAFLD progresses to HCC (82). The network of factors that predict NAFLD progression to NASH and carcinogenesis are poorly understood, hence the importance of appropriate pre-clinical models to further our knowledge in this particular setting $(83,84)$.

Several diet-induced mouse models exist that induce HCC; however, not all models replicate all the associated metabolic dysfunctions that are characteristic of human NAFLD. Feeding rodents a diet deficient in choline (CD), for instance, is known to induce hepatic steatosis and progression to HCC (85). This has first been observed in rats $(86,87)$ and confirmed in a number of mouse strains $(88)$. Mechanistically, choline deficiency leads to defects in phospholipid synthesis, lipoprotein secretion, oxidative damage, endoplasmic reticulum (ER) stress, and cell death (85). Diets that combine choline with methionine deficiency (MCD) induce even more severe pathology, characterized by steatohepatitis within 1-2 weeks and fibrosis by 8-10 weeks of feeding $(89,90)$. However, both CD and MCD are not accompanied by other physiological hallmarks of the metabolic syndrome, namely dyslipidemia, glucose intolerance, and insulin resistance (91). Furthermore, these diets promote severe body weight loss and morbidity, 
A
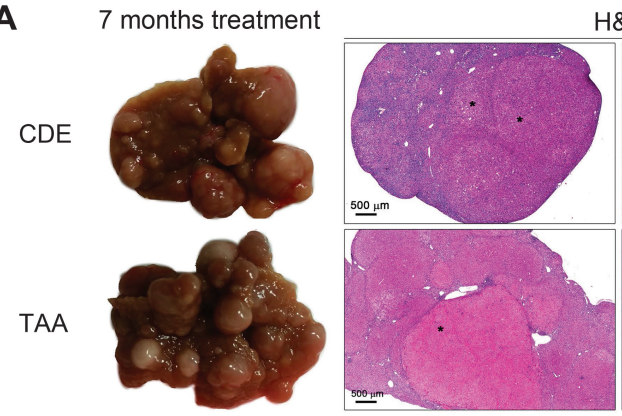

H\&E

Reticulin
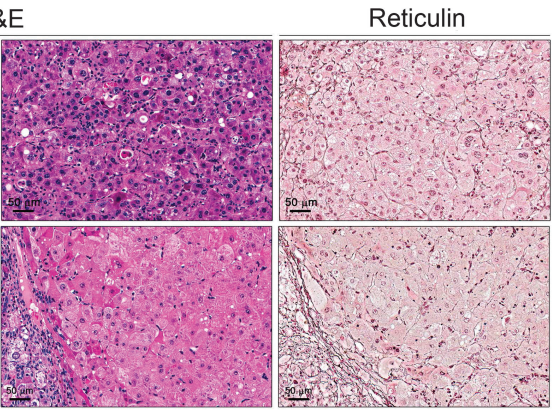

B
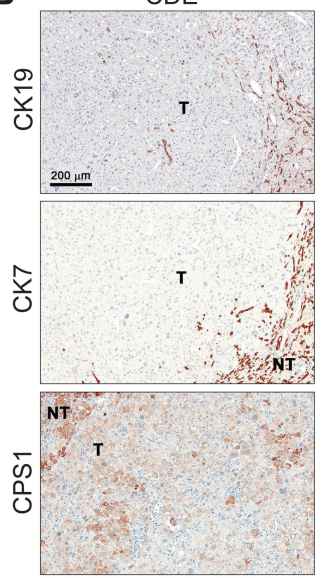

TAA

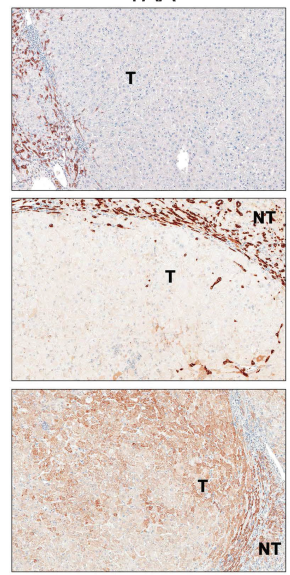

C

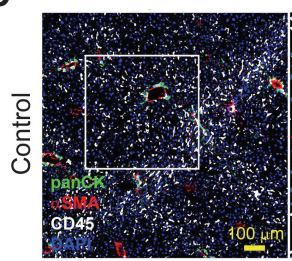

Magnification
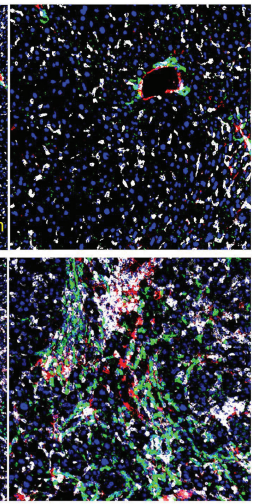

แ
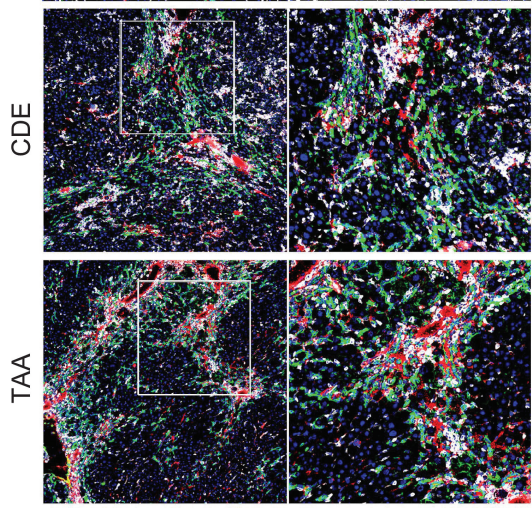

Figure 2 Histology and cellular characterization of CDE- and TAA-induced tumors. (A) Gross liver morphology assessment of $\mathrm{C} 57 \mathrm{BL} / 6 \mathrm{~J}$ mice treated with CDE or TAA for 7 months demonstrates the development of advanced tumors. Hematoxylin and eosin (H\&E) stains reveal the presence of a great variety of neoplastic changes and nodules. TAA-induced tumors comprise large polygonal cells with abundant eosinophilic cytoplasm and atypical stripped nuclei as well as moderate basophilic cell infiltrates. Similar characteristics are identified in CDE-induced tumors, although with weaker eosinophilic cytoplasm and enriched small basophilic cells. An altered stromal network of collagen III-composing fibers demonstrates the characteristic thickening of hepatic cell plates and diffuse reticulin structures within tumors. Reticulin crowding at the interface of tumorous and non-tumorous tissue indicates invasive tumor growth into the surrounding tissue. (B) Immunohistochemical staining of both CDE- and TAA-induced tumors with the biliary and liver progenitor cell markers cytokeratin 19 (CK19) and CK7 and the hepatocellular carcinoma (HCC) marker carbamamoyl phosphate synthetase I (CPS1) identifies the tumors as HCC with biliary and progenitor proliferation almost exclusively in extra-tumoral tissue. (C) Fluorescent labeling of the cellular components of the injury and regeneration niche, which hosts panCK+ biliary and progenitor cells (green), alpha-smooth muscle actin (aSMA)+ hepatic stellate cells (red) and CD45+ inflammatory cells (white), illustrates the cells' close spatial relationship and potential for cellular cross-talk in the tumor-surrounding tissue of CDE and TAA mice. NT, non-tumor; T, tumor. 
and thus, they are generally not suitable for long-term experiments leading up to HCC. In order to significantly reduce the time to carcinogenesis, ethionine, a non-proteinogenic cytotoxic methionine analogue, can be added to the CD diet $(\mathrm{CDE})$ and induce severe hepatic inflammation with a strong proliferation of liver progenitor cells and activation of fibrosis-driving hepatic stellate cells in as early as 2 weeks of feeding (92). Long-term CDE feeding of C57Bl/6 mice induced HCC in $75 \%$ of animals, whereby tumor development was significantly inhibited following treatment with the multi-tyrosine kinase inhibitor imatinib mesylate (93). Features of CDE-induced HCC after 7 months of treatment are demonstrated in Figure 2 in comparison with tumors provoked by TAA administration.

The HFD model involves feeding animals ad libitum diets containing a total of $45 \%$ to $75 \%$ calories intake derived from fats (94). Several formulations exist in which the types and percentages of fats vary significantly (95). In this model, hepatic steatosis, characterized by increased liver triglyceride accumulation and fatty acid synthesis, is accompanied by other features of the metabolic syndrome such as obesity, glucose intolerance, and insulin resistance (96). It is a very reliable model to induce simple hepatic steatosis; however, in most mouse strains, no additional liver damage and inflammation, neither development to HCC, are observed (83).

To produce a model that more closely resembles the human disease, Tetri et al. developed a formulation containing nutrients commonly found in fast foods and kept mice under conditions designed to encourage sedentary behavior, the socalled American Lifestyle-Induced Obesity Syndrome (ALIOS) model (97). The formulation included trans-fats and high-fructose corn syrup, in addition to removal of cage racks to promote low energy expenditure. After 16 weeks under this regime, mice developed severe hepatic steatosis, associated with necrosis and inflammation. Histological features of human NASH such as ballooning hepatocytes and Mallory hyaline were also described. Fibrogenesis was not detected histologically; however, procollagen mRNA expression was found to be upregulated, suggesting that fibrosis might develop at time points later than 16 weeks (97). Consistent with this hypothesis, a separate study used 12-month exposure to the ALIOS protocol and revealed fibrosis with severity ranging from mild periportal to bridging fibrosis (98). These observations were accompanied by substantial activation of the liver progenitor cell niche, which was evidenced through increased numbers of cells positive for pan-cytokeratin (panCK) and sexdetermining region Y-box 9 (Sox9) throughout the parenchyma. HCC was observed in $60 \%$ of all ALIOS mice at 12 months (98). These studies demonstrate that diet and lifestyle interventions are sufficient for the induction of NASH and hepatocarcinogenesis in mice. Future studies are necessary to assess the level of similarities between the genetics and transcriptomics of carcinogenesis observed in ALIOS mice compared to human HCC.

Another western diet model, comprised of high cholesterol, high saturated fat, and high fructose, has been shown to promote NASH, which was characterized by pronounced hepatocyte ballooning and progressive fibrosis after 6 months of feeding (99). No HCC was observed at 6 months, but it resulted in $89 \%$ incidence of spontaneous HCC after 12 months of feeding to a stable isogenic cross between C57BL/6J and S129 mice (100). Interestingly, this model, named Diet-Induced 
Animal Model Of Non-alcoholic fatty liver Disease (DIAMOND), presented remarkable histologic and transcriptomic similarities with human NASH and HCC. Tsuchida et al. recently demonstrated that the same diet, combined with low weekly doses of $\mathrm{CCl}_{4}$, can develop rapid progression to stage 3 fibrosis and HCC within 12 and 24 weeks, respectively. The pathology closely mimicked histological, immunological, and transcriptomic features of human NASH, thus representing a rapid induction model suitable to study hepatocarcinogenesis in a clinically relevant setting (101).

Most recently, another diet-induced model of NASH-driven HCC was established through genetically induced predisposition to HCC. Feeding of a HFD to major urinary protein (MUP)-urokinase-type plasminogen activator (uPA) transgenic mice, which overexpress uPA specifically in hepatocytes, induced liver disease that recapitulated several hallmarks of human NASH and reliable progression to HCC (102). In comparison with HFD-fed control wild-type animals, MUP-uPA mice displayed increased activation of hepatic stellate cells as well as upregulation of collagen and other fibrogenic markers. Immune cell infiltration, bridging fibrosis, and ballooning hepatocytes were all present in MUP-uPA mice at 24 weeks after diet initiation. Hepatocarcinogenesis was observed at 32-40 weeks of HFD feeding in about $78.6 \%$ of these animals. The mechanism of disease progression involved excessive ER stress, induced by hepatocyte overexpression of UPA and exacerbated by HFD, as well as tumor necrosis factor (TNF)-dependent inflammation (102). This model was later used to demonstrate the key role of caspase-2, downstream of TNF and ER stress, in mediating the activation of sterol regulatory element-binding proteins (SREBP), recognized to participate in NASH development (103).

\section{GENETICALLY ENGINEERED MODELS}

Human HCC is known to have a very high level of inter- and intra-tumor genetic heterogeneity (104). Illustrating this concept, a study by Schulze and colleagues employed exome sequencing analysis and identified mutations in 161 distinct putative driver genes in a cohort of only 243 hepatic tumors (105). In addition, a recent study published by the Cancer Genome Atlas Research Network investigated 383 HCC cases by whole-exome sequencing and DNA copy number analyses and assessed 196 HCC samples for their DNA methylation, RNA, miRNA, and proteomic status. The comprehensive data set, coupled with robust statistical power by the large investigated cohort, enabled the identification of various molecular signatures, which may be therapeutically targeted in different HCC subgroups (106). The individual roles of many of the identified genes and pathways in hepatocarcinogenesis have been, and continue to be, determined using mouse genetics. Such models are excellent tools to investigate the discrete effects of candidate oncogenes or tumor suppressor genes in HCC. The number of genetically engineered mouse models of HCC is very large and continuously expanding. Moreover, comprehensive reviews describing available models have been published elsewhere (107). The scope of this chapter is to present a few of the most commonly used and well-characterized genetic models in detail. 


\section{$\mathrm{c}-\mathrm{Myc}$}

The transcription factor c-Myc controls numerous cellular processes, including cell cycle progression and proliferation. Mutations that activate c-Myc are known to be highly associated with carcinogenesis in human HCC (108). Transgenic mice, overexpressing c-Myc specifically in the liver, develop hepatic tumors with a relatively long latency of approximately 12-15 months (109-111). Tumor incidence is of about $40 \%$ at 45 weeks of age, $60 \%$ at 55 weeks, and $80 \%$ at 65 weeks (111). To limit oncogene expression to the hepatic tissue, the albumin promoter has most commonly been utilized due to its specificity to hepatocytes (11). When c-Myc was combined with transgene expression of growth factors such as transforming growth factor alpha (TGF- $\alpha$ ) and hepatocyte growth factor (HGF), opposing results were obtained. Combination with TGF- $\alpha$ led to a significant acceleration of the neoplastic development, with tumors developing before 16 weeks of age (110). In contrast, HGF prevented malignant transformation when investigated in a similar setting (112). Interestingly, the kinetics of carcinogenesis induced by c-Myc can be drastically accelerated to under 40 days by co-treatment with the hepatotoxins $\mathrm{CCl}_{4}$ or 5-diethoxycarbonyl-1,4-dihydrocollidine (DDC) (113). An elegant study by Shachaf and colleagues demonstrated that inactivation of the MYC oncogene resulted in tumor regression, accompanied by differentiation of the tumor cells into hepatocytes and cholangiocytes. The tumors lay dormant until c-Myc was reactivated in cells the authors proposed to be cancer stem celllike cells (114).

The E2F transcription factor 1 (E2Fl) has also been identified as frequently dysregulated and/or mutated and was demonstrated to induce HCC in mice upon hepatic transgenic overexpression $(115,116)$. E2F1 mice showed signs of hepatic alterations as early as 2 months of age, with most animals developing adenomas at 6 months. However, tumors progressed to HCC only in one-third of experimental animals at 1 year of age. Co-expression of E2Fl and c-Myc further accelerated the appearance of focal lesions and severe dysplasia, leading to earlier development of HCC as compared to either of the oncogenes alone (117).

\section{Wnt/ $\beta$-catenin}

Wnt/ $\beta$-catenin signaling controls a plethora of cellular communication networks in embryonic development and demonstrates key roles in regulating stemness and cell differentiation in health and disease (118). Pathological alterations of this pathway are known for its involvement in many human cancers, including liver cancer $(118,119)$. Beta-catenin is one of the key effectors of Wnt signaling, and its gene CTNNB1 is the most frequently found mutated component of this pathway in human HCC (120). Altered activity of $\beta$-catenin, as evidenced by mutation or nuclear translocation, was observed as an early event in hepatocarcinogenesis driven by distinct genetic models (121). Yet, constitutive activation of $\beta$-catenin through deletion of its regulatory domain was not sufficient to promote hepatic tumorigenesis by itself (122). When combined with oncogenic H-ras (H-ras $\left.{ }^{\mathrm{G} 12 \mathrm{~V}}\right)$, however, $\beta$-catenin activation resulted in aggressive HCC development with $100 \%$ incidence within 3-4 months following the genetic manipulation (123). 
Interestingly, the most commonly used approach to induce hepatic $\beta$-catenin activation in mice has been the selective Cre-Lox disruption of its negative regulator, adenomatous polyposis coli (Apc). This indirect approach for the stabilization of active $\beta$-catenin was shown to lead to spontaneous hepatocyte hyperplasia and $67 \%$ incidence of HCC in the surviving animals following 8-9 months of model establishment (124). Tumors generated through this model have recently been shown to possess a unique metabolic signature, characterized by exacerbated fatty acid utilization (125), suggesting that inhibition of fatty acid oxidation could be a potential therapeutic approach for $\beta$-catenin-induced HCC.

\section{Liver-specific knockout models}

Liver-specific knockout models of tumor suppressor genes have also been developed and utilized either alone or in combination with other insults to study liver cancer. The TP53 gene that encodes for the tumor suppressor p53 is found mutated in most human cancers, including HCC (126). P53 knockout mice displayed a significantly increased hepatocyte proliferation rate and LPC-like cells in periportal liver regions (127). In addition, p53-/-LPCs isolated from these mice and injected subcutaneously into athymic nude mice generated tumors with a HCC morphology (128). In a separate study, the homozygous deletion of Trp53 (the mouse ortholog), specifically in the liver, led to HCC formation after 14 months of age (129). The authors also showed that p53 deletion gave raise to tumors with a bilineal phenotype and increased proliferation of liver progenitor cells. These observations support a model in which loss of function of p53 may promote HCC through an increase in the proliferative capacity of progenitor cells.

Another ubiquitously expressed tumor suppressor gene frequently found mutated or downregulated in human HCC is phosphatase and tensin homolog (PTEN) (130, 131). Its phosphatase activity inhibitsphosphatidylinositol-3kinases (PI3K) and consequently suppresses downstream protein kinase B (PKB/ Akt) and mammalian target of rapamycin (mTOR) growth-promoting signaling. Horie et al. generated a liver-specific PTEN knockout model through the crossing of albumin promoter Cre mice with PTEN-floxed mice (132). The resulting conditional PTEN knockout mice showed hepatomegaly and steatosis as early as 10 weeks of age. At 40 weeks, features of NASH including hepatic inflammation and fibrosis were observed. This model also reliably progressed to tumorigenesis, although with a long latency. The incidence of hepatic adenomas was $47 \%$ at 44 weeks, and by 74-78 weeks, 66\% of animals displayed HCC (132). The mechanism of carcinogenesis driven by PTEN disruption has later been addressed. It involves hepatic injury-dependent expansion of epithelial cellular adhesion molecule (EpCAM), alpha-fetoprotein (AFP), and cytokeratin 19 (CK-19) positive progenitor cells (133).

\section{Hydrodynamic tail vein injection (HTVI) models}

Traditionally, genetic modifications, such as gene knockouts, knockins, and transgene overexpression, were introduced in the germline of parent mouse strains to produce whole body genetic alterations (134). This approach has been extensively used in HCC research; however, advances in genetic manipulation tools, such as 
Cre-Lox recombination, have allowed for a much more precise spatial and temporal control of candidate genes expression, and their utilization has become widespread (135). Notably, this kind of approach has been used to produce conditional liver-specific genetic manipulations, overcoming the problem of embryonic lethal gene mutations as well as restricting phenotypes to the hepatic tissue. Nonetheless, these are both expensive and time-consuming strategies.

A simple and inexpensive alternative method to transfect and gene-edit hepatocytes in vivo is represented by hydrodynamic tail vein injection (HTVI) of "naked" plasmid DNA (non-viral vector, not associated with protective proteins or lipids) directly into the liver of adult mice $(136,137)$. The technique consists of rapid injection of a large amount of plasmid DNA (about $50 \mu \mathrm{g}$ in a volume of saline that signifies $10 \%$ of the body weight of the injected mouse) into the mouse lateral tail vein (138). HTVI results in transient heart dysfunction and fluid accumulation in the inferior vena cava. The enormous hydrodynamic pressure then forces the fluid into the liver in a retrograde movement, enlarges the liver, and pushes the plasmid DNA into hepatocytes via enlarged sinusoidal fenestrae and transient membrane pores (139), with transfection efficiencies ranging from around 10 to $40 \%$ of all hepatocytes $(136,140)$. While the liver is primarily targeted, other organs including heart, kidney, lung, and spleen are also affected by HTVI; however, to only $0.1 \%$ of the levels achieved in the liver $(138,141)$. One caveat of HTVI is that the expression of transfected genes is transient, peaking within $24 \mathrm{~h}$, but dropping dramatically thereafter (142). In order to circumvent this pitfall, HTVI has been combined with DNA recombination technologies such as Cre-Lox, sleeping beauty (SB) transposase, and CRISPR-Cas9, allowing for genomic integration and continuous expression of genetic modifications. HTVI has been used increasingly to study genetic factors influencing HCC biology, and a variety of HCC models have recently been developed using this approach. Particularly, HTVI permits the assessment of more than one genetic alteration at the same time and therefore the investigation of the combinatory effects of targeting multiple pathways simultaneously. A number of models created through HTVI are discussed below and are summarized in Figure 3.

The PI3K/AKT/mTOR pathway is central in the regulation of hepatocyte cell metabolism, growth, and proliferation (143). Upregulation of this pathway is frequently observed in human HCC $(144,145)$ and is associated with poorer outcomes (146). As described before, conditional liver knockout of PTEN, a negative regulator of this pathway, induces NASH-like liver disease and HCC in mice (132). HTVI was used to introduce a constitutively active form of AKT (myristoylated AKT) that induced HCC about 6 months post-injection (147). Wild-type mice were co-injected with SB transposase and active AKT vectors for somatic integration. Disease progression resembled that of PTEN knockout mice, with increased lipogenesis and upregulation of genes involved in fatty acid synthesis (147). Importantly, the expression of transfected AKT was observed in relatively few cells, which were surrounded by non-transfected hepatocytes. This is considered to be an advantage of HTVI, in that it better resembles human liver cancer, where only a limited number of foci are believed to give rise to HCC (140).

It was later reported that co-injection of AKT along with H-ras ${ }^{\mathrm{G} 12 \mathrm{~V}}$ significantly increases the kinetics of liver tumor development, with 100\% of injected animals presenting tumors within 4 weeks post-injection (148). Similar kinetics were observed when AKT was co-expressed with active $\beta$-catenin (149). 
Fast (5-8s) injection into lateral tail vein ( $50 \mu \mathrm{g}$ plasmid DNA in $2.5 \mathrm{ml}$ saline)

Cre-Lox, sleeping beauty transposase, and/or CRISPR-Cas9-based plasmids

Myristoylated AKT [HCC in 6 months (145)]

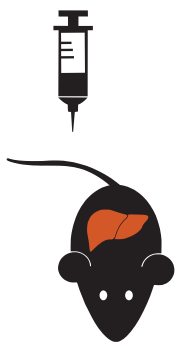

Myristoylated AKT + H-rasG12V [HCC in 4 weeks (146)]

Myristoylated AKT + active $\beta$-catenin [HCC in 4 weeks (147)]

$\mathrm{H}$-rasG12V in p19ARF KO background [HCC in 6 weeks (148)]

H-rasG12V + Trp53 shRNA [HCC in 4 weeks (149)]

CRISPR-Cas9-mediated PTEN and Trp53 double KO

[HCC in 3 months (153)]

Variable latency depending on model

Co-injection of luciferase expression cassette allows for in vivo monitoring of tumour growth

by bioluminescence imaging (BLI) (149)

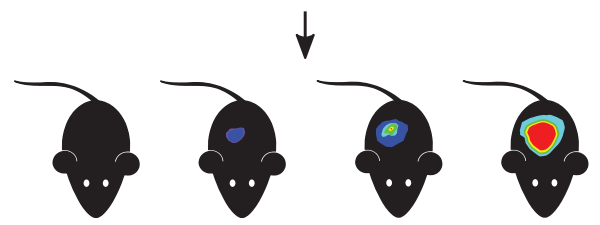

Figure 3 Hydrodynamic tail vein injection models of hepatocellular carcinoma. Plasmid DNA containing Cre-Lox, sleeping beauty transposase, and/or CRISPR-Cas9-based recombination sequences along with key oncogenes or tumor suppressor disruption sequences is injected into the lateral tail vein of young mice. HCC develops with variable latency depending on the chosen genetic manipulation, as indicated. Co-injection of luciferase expression cassette allows for in vivo monitoring of tumor growth by bioluminescence imaging (BLI). HCC, hepatocellular carcinoma; $\mathrm{KO}$, knockout.

Interestingly, injection of $\mathrm{H}-\mathrm{ras}^{\mathrm{G} 12 \mathrm{~V}}$ alone did not lead to $\mathrm{HCC}(148,150)$. However, when expressed in p19 Arf knockout mice, H-ras ${ }^{G 12 V}$ induced HCC in all mice within 6 weeks that otherwise did not develop with simple disruption of this positive regulator of p53 (150). In a similar way, H-ras ${ }^{\mathrm{G} 12 \mathrm{~V}}$ combined with a shRNA construct targeting p53 led to hepatocarcinogenesis within only 4 weeks (151). This study also demonstrated that oncogenic vectors can be combined with a SB transposase plasmid containing a firefly luciferase expression cassette, allowing for tumor growth to be monitored non-invasively over time through bioluminescence imaging. Altogether, these results highlight the suitability of HTVI to create models that allow for the utilization of synergistic pathways in promoting HCC for rapid induction studies and proof-of-concept therapeutic interventions.

Notably, the SB transposase system permits efficient genomic recombination of exogenous sequences; however, this approach is not specific in terms of the integration site (152). Recombination can potentially occur virtually anywhere in the 
genome, causing undesired disruption of off-target genes (153). The CRISPRCas9 system, on the other hand, offers sequence-specific direct editing of DNA with only rare off-target mutations (154). In a proof-of-concept study, Xue et al. utilized HTVI to generate CRISPR-Cas9-mediated knockouts of PTEN and p53, or combinations of the two, that phenocopied the traditional conditional liver knockouts of these genes (155). PTEN and/or p53 disruptions were shown to be present in 3 to $6 \%$ of all hepatocytes. At 3 months post-injection, all animals with double disruptions developed liver tumors (155). The same approach was used to target $\beta$-catenin and simultaneously introduced a constitutively active version of it. This notoriously less-efficient event, observed in only $0.5 \%$ of all hepatocytes, however, demonstrated that CRISPR-Cas9 can also be used to introduce gain-offunction mutations, providing a highly specific and low off target method for the evaluation of novel gene roles in HCC development (155). Consequently, CRISPRCas9 combined with HTVI has been increasingly utilized for HCC research in recent years (156-158).

\section{CONCLUSION}

HCC poses a global health challenge in terms of prevention, diagnosis, and treatment. While epidemiological studies can provide information on associations between HCC and variables that influence its natural history, the progression of interventions into clinical practice requires demonstrated benefits and safety from carefully designed in vivo models such as the mouse models described here. A large variety of experimental chronic liver injury and HCC models are currently available, each with particular characteristic features, mimicking diverse etiologies and disease progression patterns. Selection of the most appropriate animal model allows for the study of disease context-specific as well as common carcinogenic mechanisms and screening of novel therapeutic targets for clinical translation. Until the tyrosine kinase inhibitor sorafenib was approved for unresectable HCC in 2007, there was no FDA-approved therapies available for patients in advanced-stage chronic liver disease. The improved understanding of the molecular mechanisms of HCC, primarily obtained from several of the animal models herein described, has culminated in the development of current targeted therapies, including sorafenib and regorafenib. Several other agents have been tested, or are currently under clinical evaluation, and will hopefully contribute to improved HCC outcomes in the years to come. There is no perfect animal model for human disease; however, mouse models are still invaluable and will continue to form the cornerstone of preclinical studies, designed to delineate interventions that are effective and safe in the future.

Acknowledgments: The authors thank the School of Pharmacy and Biomedical Sciences and the Curtin Health Innovation Research Institute at Curtin University for their support and excellent research facilities.

Conflict of Interest: The authors declare no potential conflicts of interest with respect to research, authorship, and/or publication of this article. 
Copyright and Permission Statement: To the best of our knowledge, the materials included in this chapter do not violate copyright laws. All original sources have been appropriately acknowledged and/or referenced.

\section{REFERENCES}

1. Allemani C, Matsuda T, Di Carlo V, Harewood R, Matz M, Niksic M, et al. Global surveillance of trends in cancer survival 2000-14 (CONCORD-3): Analysis of individual records for 37513025 patients diagnosed with one of 18 cancers from 322 population-based registries in 71 countries. Lancet. 2018;391(10125):1023-75. http://dx.doi.org/10.1016/S0140-6736(17)33326-3

2. Global Burden of Disease Cancer C, Fitzmaurice C, Akinyemiju TF, Al Lami FH, Alam T, AlizadehNavaei R, et al. Global, regional, and national cancer incidence, mortality, years of life lost, years lived with disability, and disability-adjusted life-years for 29 cancer groups, 1990 to 2016: A systematic analysis for the global burden of disease study. JAMA Oncol. 2018;4(11):1553-68. http://dx.doi. org/10.1001/jamaoncol.2018.2706

3. Forner A, Llovet JM, Bruix J. Hepatocellular carcinoma. Lancet. 2012;379(9822):1245-55. http:// dx.doi.org/10.1016/S0140-6736(11)61347-0

4. Massarweh NN, El-Serag HB. Epidemiology of hepatocellular carcinoma and intrahepatic cholangiocarcinoma. Cancer Control. 2017;24(3):1073274817729245. http://dx.doi.org/10.1177 $/ 1073274817729245$

5. Forner A, Reig M, Bruix J. Hepatocellular carcinoma. Lancet. 2018;391(10127):1301-14. http:// dx.doi.org/10.1016/S0140-6736(18)30010-2

6. Marra F, Lotersztajn S. Pathophysiology of NASH: Perspectives for a targeted treatment. Curr Pharm Des. 2013;19(29):5250-69. http://dx.doi.org/10.2174/13816128113199990344

7. Kohn-Gaone J, Gogoi-Tiwari J, Ramm GA, Olynyk JK, Tirnitz-Parker JEE. The role of liver progenitor cells during liver regeneration, fibrogenesis, and carcinogenesis. Am J Physiol-Gastr L. 2016;310(3):G143-54. http://dx.doi.org/10.1152/ajpgi.00215.2015

8. Rosenthal N, Brown S. The mouse ascending: Perspectives for human-disease models. Nat Cell Biol. 2007;9(9):993-9. http://dx.doi.org/10.1038/ncb437

9. Zhu F, Nair RR, Fisher EMC, Cunningham TJ. Humanising the mouse genome piece by piece. Nat Commun. 2019;10(1):1845. http://dx. doi.org/10.1038/s41467-019-09716-7

10. Kohn-Gaone J, Dwyer BJ, Grzelak CA, Miller G, Shackel NA, Ramm GA, et al. Divergent inflammatory, fibrogenic, and liver progenitor cell dynamics in two common mouse models of chronic liver injury. Am J Pathol. 2016;186(7):1762-74. http://dx.doi.org/10.1016/j.ajpath.2016.03.005

11. Heindryckx F, Colle I, Van Vlierberghe H. Experimental mouse models for hepatocellular carcinoma research. Int J Exp Pathol. 2009;90(4):367-86. http://dx.doi.org/10.1111/j.1365-2613.2009.00656.x

12. Sethi V, Kurtom S, Tarique M, Lavania S, Malchiodi Z, Hellmund L, et al. Gut microbiota promotes tumor growth in mice by modulating immune response. Gastroenterology. 2018;155(1):33-7 e6. http://dx.doi.org/10.1053/j.gastro.2018.04.001

13. Verna L, Whysner J, Williams GM. N-nitrosodiethylamine mechanistic data and risk assessment: Bioactivation, DNA-adduct formation, mutagenicity, and tumor initiation. Pharmacol Ther. 1996;71(1-2):57-81. http://dx.doi.org/10.1016/0163-7258(96)00062-9

14. Sanchez-Perez Y, Carrasco-Legleu C, Garcia-Cuellar C, Perez-Carreon J, Hernandez-Garcia S, SalcidoNeyoy M, et al. Oxidative stress in carcinogenesis. Correlation between lipid peroxidation and induction of preneoplastic lesions in rat hepatocarcinogenesis. Cancer Lett. 2005;217(1):25-32. http:// dx.doi.org/10.1016/j.canlet.2004.07.019

15. Teoh NC, Dan YY, Swisshelm K, Lehman S, Wright JH, Haque J, et al. Defective DNA strand break repair causes chromosomal instability and accelerates liver carcinogenesis in mice. Hepatology. 2008;47(6):2078-88. http://dx.doi.org/10.1002/hep.22194

16. Shiota G, Harada K, Ishida M, Tomie Y, Okubo M, Katayama S, et al. Inhibition of hepatocellular carcinoma by glycyrrhizin in diethylnitrosamine-treated mice. Carcinogenesis. 1999;20(1):59-63. http://dx.doi.org/10.1093/carcin/20.1.59 
17. Park TJ, Kim JY, Oh SP, Kang SY, Kim BW, Wang HJ, et al. TIS2l negatively regulates hepatocarcinogenesis by disruption of cyclin B1-Forkhead box Ml regulation loop. Hepatology. 2008;47(5): 1533-43. http://dx.doi.org/10.1002/hep.22212

18. Finnberg N, Stenius U, Hogberg J. Heterozygous p53-deficient (+/-) mice develop fewer p53-negative preneoplastic focal liver lesions in response to treatment with diethylnitrosamine than do wild-type (+/+) mice. Cancer Lett. 2004;207(2):149-55. http://dx.doi.org/10.1016/j.canlet.2003.11.013

19. De Minicis S, Kisseleva T, Francis H, Baroni GS, Benedetti A, Brenner D, et al. Liver carcinogenesis: Rodent models of hepatocarcinoma and cholangiocarcinoma. Dig Liver Dis. 2013;45(6):450-9. http://dx.doi.org/10.1016/j.dld.2012.10.008

20. Cunningham ML, Matthews HB. Cell proliferation as a determining factor for the carcinogenicity of chemicals: Studies with mutagenic carcinogens and mutagenic noncarcinogens. Toxicol Lett. 1995;82-3:9-14. http://dx.doi.org/10.1016/0378-4274(95)03464-1

21. Vesselinovitch SD, Mihailovich N. Kinetics of diethylnitrosamine hepatocarcinogenesis in the infant mouse. Cancer Res. 1983;43(9):4253-9.

22. Sarma DSR, Rao PM, Rajalakshmi S. Liver-tumor promotion by chemicals—Models and mechanisms. Cancer Surv. 1986;5(4):781-98.

23. Bigsby RM, Caperell-Grant A. The role for estrogen receptor-alpha and prolactin receptor in sexdependent DEN-induced liver tumorigenesis. Carcinogenesis. 2011;32(8):1162-6. http://dx.doi. org/10.1093/carcin/bgr094

24. Naugler WE, Sakurai T, Kim S, Maeda S, Kim K, Elsharkawy AM, et al. Gender disparity in liver cancer due to sex differences in MyD88-dependent IL-6 production. Science. 2007;317(5834):121-4. http://dx.doi.org/10.1126/science.1140485

25. Satoh K, Itoh K, Yamamoto M, Tanaka M, Hayakari M, Ookawa K, et al. Nrf2 transactivator-independent GSTP1-1 expression in 'GSTP1-1 positive' single cells inducible in female mouse liver by DEN: A preneoplastic character of possible initiated cells. Carcinogenesis. 2002;23(3):457-62. http://dx.doi. org/10.1093/carcin/23.3.457

26. Hanigan MH, Winkler ML, Drinkwater NR. Induction of three histochemically distinct populations of hepatic foci in C57BL/6J mice. Carcinogenesis. 1993;14(5):1035-40. http://dx.doi.org/10.1093/ carcin/14.5.1035

27. Poole TM, Drinkwater NR. Strain dependent effects of sex hormones on hepatocarcinogenesis in mice. Carcinogenesis. 1996;17(2):191-6. http://dx.doi.org/10.1093/carcin/17.2.191

28. Nakatani T, Roy G, Fujimoto N, Asahara T, Ito A. Sex hormone dependency of diethylnitrosamine-induced liver tumors in mice and chemoprevention by leuprorelin. Jpn J Cancer Res. 2001;92(3):249-56. http://dx.doi.org/10.1111/j.1349-7006.2001.tb01089.x

29. Bosch FX, Ribes J, Diaz M, Cleries R. Primary liver cancer: Worldwide incidence and trends. Gastroenterology. 2004;127(5 Suppl 1):S5-S16. http://dx.doi.org/10.1053/j.gastro.2004.09.011

30. He G, Karin M. NF-kappaB and STAT3-Key players in liver inflammation and cancer. Cell Res. 2011;21(1):159-68. http://dx.doi.org/10.1038/cr.2010.183

31. Tolba R, Kraus T, Liedtke C, Schwarz M, Weiskirchen R. Diethylnitrosamine (DEN)induced carcinogenic liver injury in mice. Lab Anim. 2015;49(1 Suppl):59-69. http://dx.doi. org/10.1177/0023677215570086

32. Farazi PA, DePinho RA. Hepatocellular carcinoma pathogenesis: From genes to environment. Nat Rev Cancer. 2006;6(9):674-87. http://dx.doi.org/10.1038/nrc1934

33. Chen X, Yamamoto M, Fujii K, Nagahama Y, Ooshio T, Xin B, et al. Differential reactivation of fetal/ neonatal genes in mouse liver tumors induced in cirrhotic and non-cirrhotic conditions. Cancer Sci. 2015;106(8):972-81. http://dx.doi.org/10.1111/cas.12700

34. Alkofer B, Lepennec V, Chiche L. Hepatocellular cancer in the non-cirrhotic liver. J Visc Surg. 2011;148(1):3-11. http://dx.doi.org/10.1016/j.jviscsurg.2010.12.012

35. Delire B, Starkel P, Leclercq I. Animal models for fibrotic liver diseases: What we have, what we need, and what is under development. J Clin Transl Hepatol. 2015;3(1):53-66. http://dx.doi.org/10.14218/ JCTH.2014.00035

36. Dong S, Chen QL, Song YN, Sun Y, Wei B, Li XY, et al. Mechanisms of CCl4-induced liver fibrosis with combined transcriptomic and proteomic analysis. J Toxicol Sci. 2016;41(4):561-72. http:// dx.doi.org/10.2131/jts. 41.561 
37. Johansson I, Ingelmansundberg M. Carbon tetrachloride-induced lipid-peroxidation dependent on an ethanol-inducible form of rabbit liver microsomal cytochrome-P-450. Febs Lett. 1985;183(2):265-9. http://dx.doi.org/10.1016/0014-5793(85)80790-0

38. Sheweita SA, Abd El-Gabar M, Bastawy M. Carbon tetrachloride changes the activity of cytochrome P450 system in the liver of male rats: Role of antioxidants. Toxicology. 2001;169(2):83-92. http:// dx.doi.org/10.1016/50300-483X(01)00473-5

39. Poli G, Cheeseman K, Slater TF, Dianzani MU. The role of lipid peroxidation in CCl4-induced damage to liver microsomal enzymes: Comparative studies in vitro using microsomes and isolated liver cells. Chem Biol Interact. 1981;37(1-2):13-24. http://dx.doi.org/10.1016/0009-2797(81)90162-9

40. Sheweita SA, El-Gabar MA, Bastawy M. Carbon tetrachloride changes the activity of cytochrome P450 system in the liver of male rats: Role of antioxidants. Toxicology. 2001;169(2):83-92. http://dx.doi. org/10.1016/S0300-483X(01)00473-5

41. Ozturk F, Gul M, Ates B, Ozturk IC, Cetin A, Vardi N, et al. Protective effect of apricot (Prunus armeniaca L.) on hepatic steatosis and damage induced by carbon tetrachloride in Wistar rats. Br J Nutr. 2009;102(12):1767-75. http://dx.doi.org/10.1017/S0007114509991322

42. Muriel P, Escobar Y. Kupffer cells are responsible for liver cirrhosis induced by carbon tetrachloride. J Appl Toxicol. 2003;23(2):103-8. http://dx.doi.org/10.1002/jat.892

43. Karlmark KR, Weiskirchen R, Zimmermann HW, Gasssler N, Ginhoux F, Weber C, et al. Hepatic recruitment of the inflammatory $\mathrm{Grl}(+)$ monocyte subset upon liver injury promotes hepatic fibrosis. Hepatology. 2009;50(1):261-74. http://dx.doi.org/10.1002/hep.22950

44. Yamada Y, Fausto N. Deficient liver regeneration after carbon tetrachloride injury in mice lacking type 1 but not type 2 tumor necrosis factor receptor. Am J Pathol. 1998;152(6):1577-89.

45. Shi ZD, Wakil AE, Rockey DC. Strain-specific differences in mouse hepatic wound healing are mediated by divergent T helper cytokine responses. P Natl Acad Sci U S A. 1997;94(20):10663-8. http:// dx.doi.org/10.1073/pnas.94.20.10663

46. Brenner DA, Veloz L, Jaenisch R, Alcorn JM. Stimulation of the collagen alpha-1(I) endogenous gene and transgene in carbon-tetrachloride induced hepatic-fibrosis. Hepatology. 1993;17(2):287-92. http://dx.doi.org/10.1002/hep.1840170220

47. Black D, Bird MA, Samson CA, Lyman S, Lange PA, Schrum LW, et al. Primary cirrhotic hepatocytes resist TGF beta-induced apoptosis through a ROS-dependent mechanism. J Hepatol. 2004;40(6): 942-51. http://dx.doi.org/10.1016/j.jhep.2004.02.031

48. Nagano K, Sasaki T, Umeda Y, Nishizawa T, Ikawa N, Ohbayashi H, et al. Inhalation carcinogenicity and chronic toxicity of carbon tetrachloride in rats and mice. Inhal Toxicol. 2007;19(13):1089-103. http://dx.doi.org/10.1080/08958370701628770

49. Fujii T, Fuchs BC, Yamada S, Lauwers GY, Kulu Y, Goodwin JM, et al. Mouse model of carbon tetrachloride induced liver fibrosis: Histopathological changes and expression of CD133 and epidermal growth factor. BMC Gastroenterol. 2010;10:79. http://dx.doi.org/10.1186/1471-230X-10-79

50. Scholten D, Trebicka J, Liedtke C, Weiskirchen R. The carbon tetrachloride model in mice. Lab Anim. 2015;49(1 Suppl):4-11. http://dx.doi.org/10.1177/0023677215571192

51. Farazi PA, Glickman J, Horner J, Depinho RA. Cooperative interactions of p53 mutation, telomere dysfunction, and chronic liver damage in hepatocellular carcinoma progression. Cancer Res. 2006;66(9):4766-73. http://dx.doi.org/10.1158/0008-5472.CAN-05-4608

52. Weisburger EK. Carcinogenicity studies on halogenated hydrocarbons. Environ Health Perspect. 1977;21:7-16. http://dx.doi.org/10.1289/ehp.77217

53. Xin B, Cui Y, Wang YX, Wang L, Yin JP, Zhang LC, et al. Combined use of alcohol in conventional chemical-induced mouse liver cancer model improves the simulation of clinical characteristics of human hepatocellular carcinoma. Oncol Lett. 2017;14(4):4722-8. http://dx.doi.org/10.3892/ ol.2017.6800

54. Uehara T, Ainslie GR, Kutanzi K, Pogribny IP, Muskhelishvili L, Izawa T, et al. Molecular mechanisms of fibrosis-associated promotion of liver carcinogenesis. Toxicol Sci. 2013;132(1):53-63. http:// dx.doi.org/10.1093/toxsci/kfs342

55. Uehara T, Pogribny IP, Rusyn I. The DEN and CCl4 -Induced mouse model of fibrosis and inflammation-associated hepatocellular carcinoma. Curr Protoc Pharmacol. 2014;66:14 30 l-10. http://dx.doi. org/10.1002/0471141755.ph1430s66 
56. Sancho-Bru P, Altamirano J, Rodrigo-Torres D, Coll M, Millan C, Jose Lozano J, et al. Liver progenitor cell markers correlate with liver damage and predict short-term mortality in patients with alcoholic hepatitis. Hepatology. 2012;55(6):1931-41. http://dx.doi.org/10.1002/hep.25614

57. Katoonizadeh A, Nevens F, Verslype C, Pirenne J, Roskams T. Liver regeneration in acute severe liver impairment: A clinicopathological correlation study. Liver Int. 2006;26(10):1225-33. http://dx.doi. org/10.1111/j.1478-3231.2006.01377.x

58. Low TY, Leow CK, Salto-Tellez M, Chung MC. A proteomic analysis of thioacetamide-induced hepatotoxicity and cirrhosis in rat livers. Proteomics. 2004;4(12):3960-74. http://dx.doi.org/10.1002/ pmic. 200400852

59. Grzelak CA, Martelotto LG, Sigglekow ND, Patkunanathan B, Ajami K, Calabro SR, et al. The intrahepatic signalling niche of hedgehog is defined by primary cilia positive cells during chronic liver injury. J Hepatol. 2014;60(1):143-51. http://dx.doi.org/10.1016/j.jhep.2013.08.012

60. Boulter L, Guest RV, Kendall TJ, Wilson DH, Wojtacha D, Robson AJ, et al. WNT signaling drives cholangiocarcinoma growth and can be pharmacologically inhibited. J Clin Invest. 2015;125(3):1269-85. http://dx.doi.org/10.1172/JCI76452

61. Guest RV, Boulter L, Kendall TJ, Minnis-Lyons SE, Walker R, Wigmore SJ, et al. Cell lineage tracing reveals a biliary origin of intrahepatic cholangiocarcinoma. Cancer Res. 2014;74(4):1005-10. http:// dx.doi.org/10.1158/0008-5472.CAN-13-1911

62. McQueen CA, editor. Vol 9: Hepatic toxicology. In: Comprehensive toxicology. 2nd ed. Elsevier Science; 2010. p. 1-638.

63. Wallace MC, Hamesch K, Lunova M, Kim Y, Weiskirchen R, Strnad P, et al. Standard operating procedures in experimental liver research: Thioacetamide model in mice and rats. Lab Anim. 2015;49(1 Suppl):21-9. http://dx.doi.org/10.1177/0023677215573040

64. Strnad P, Tao GZ, Zhou Q, Harada M, Toivola DM, Brunt EM, et al. Keratin mutation predisposes to mouse liver fibrosis and unmasks differential effects of the carbon tetrachloride and thioacetamide models. Gastroenterology. 2008;134(4):1169-79. http://dx.doi.org/10.1053/j.gastro.2008.01.035

65. Munoz Torres E, Paz Bouza JI, Lopez Bravo A, Abad Hernandez MM, Carrascal Marino E. Experimental thioacetamide-induced cirrhosis of the liver. Histol Histopathol. 1991;6(1):95-100.

66. Aydin AF, Kusku-Kiraz Z, Dogru-Abbasoglu S, Gulluoglu M, Uysal M, Kocak-Toker N. Effect of carnosine against thioacetamide-induced liver cirrhosis in rat. Peptides. 2010;31(1):67-71. http:// dx.doi.org/10.1016/j.peptides.2009.11.028

67. Kornek M, Raskopf E, Guetgemann I, Ocker M, Gerceker S, Gonzalez-Carmona MA, et al. Combination of systemic thioacetamide (TAA) injections and ethanol feeding accelerates hepatic fibrosis in C3H/ He mice and is associated with intrahepatic up regulation of MMP-2, VEGF and ICAM-1. J Hepatol. 2006;45(3):370-6. http://dx.doi.org/10.1016/j.jhep.2006.03.017

68. Patsenker E, Popov Y, Stickel F, Schneider V, Ledermann M, Sagesser H, et al. Pharmacological inhibition of integrin alphavbeta3 aggravates experimental liver fibrosis and suppresses hepatic angiogenesis. Hepatology. 2009;50(5):1501-11. http://dx.doi.org/10.1002/hep.23144

69. Zaghloul RA, Elsherbiny NM, Kenawy HI, El-Karef A, Eissa LA, El-Shishtawy MM. Hepatoprotective effect of hesperidin in hepatocellular carcinoma: Involvement of Wnt signaling pathways. Life Sci. 2017;185:114-25. http://dx.doi.org/10.1016/j.lfs.2017.07.026

70. Al-Gayyar MMH, Bagalagel A, Noor AO, Almasri DM, Diri R. The therapeutic effects of nicotinamide in hepatocellular carcinoma through blocking IGF-1 and effecting the balance between Nrf2 and PKB. Biomed Pharmacother. 2019;112:108653. http://dx.doi.org/10.1016/j.biopha. 2019.108653

71. Lee HS, Choi J, Son T, Lee EJ, Kim JG, Ryu SH, et al. A-kinase anchoring protein 12 is downregulated in human hepatocellular carcinoma and its deficiency in mice aggravates thioacetamide-induced liver injury. Oncol Lett. 2018;16(5):5907-15. http://dx.doi.org/10.3892/ol.2018.9396

72. Abe M, Yoshida T, Akiba J, Ikezono Y, Wada F, Masuda A, et al. STAT3 deficiency prevents hepatocarcinogenesis and promotes biliary proliferation in thioacetamide-induced liver injury. World J Gastroenterol. 2017;23(37):6833-44. http://dx.doi.org/10.3748/wjg.v23.i37.6833

73. Sakurai T, Yada N, Watanabe T, Arizumi T, Hagiwara S, Ueshima K, et al. Cold-inducible RNAbinding protein promotes the development of liver cancer. Cancer Sci. 2015;106(4):352-8. http:// dx.doi.org/10.1111/cas.12611 
74. Mikami K, Endo T, Sawada N, Igarashi GO, Kimura M, Sakuraba H, et al. Inhibition of systemic hyaluronan synthesis exacerbates murine hepatic carcinogenesis. In Vivo. 2018;32(2):273-8. http:// dx.doi.org/10.21873/invivo.11234

75. Henderson JM, Polak N, Chen J, Roediger B, Weninger W, Kench JG, et al. Multiple liver insults synergize to accelerate experimental hepatocellular carcinoma. Sci Rep. 2018;8(1):10283. http:// dx.doi.org/10.1038/s41598-018-28486-8

76. Zhang Z, Song L, Guo J. The application of pre-clinical animal models to optimise nanoparticulate drug delivery for hepatocellular carcinoma. Pharm Nanotechnol. 2018;6(4):221-31. http://dx.doi.org $/ 10.2174 / 2211738506666181001121533$

77. Colombo M, Lleo A. The impact of antiviral therapy on hepatocellular carcinoma epidemiology. Hepat Oncol. 2018;5(1). https://www.futuremedicine.com/doi/10.2217/hep-2017-0024

78. Rehm J, Shield KD. Alcohol and mortality global alcohol-attributable deaths from cancer, liver cirrhosis, and injury in 2070. Alcohol Res-Curr Rev. 2013;35(2):174-83.

79. Pimpin L, Cortez-Pinto H, Negro F, Corbould E, Lazarus JV, Webber L, et al. Burden of liver disease in Europe: Epidemiology and analysis of risk factors to identify prevention policies. J Hepatol. 2018;69(3):718-35. http://dx.doi.org/10.1016/j.jhep.2018.05.011

80. Mak LY, Cruz-Ramon V, Chinchilla-Lopez P, Torres HA, LoConte NK, Rice JP, et al. Global epidemiology, prevention, and management of hepatocellular carcinoma. Am Soc Clin Oncol Educ Book. 2018(38):262-79. http://dx.doi.org/10.1200/EDBK_200939

81. Younossi Z, Anstee QM, Marietti M, Hardy T, Henry L, Eslam M, et al. Global burden of NAFLD and NASH: Trends, predictions, risk factors and prevention. Nat Rev Gastroenterol Hepatol. 2018;15(1):11-20. http://dx.doi.org/10.1038/nrgastro.2017.109

82. DeWeerdt S. Disease progression: Divergent paths. Nature. 2017;551(7681). http://dx.doi. org/10.1038/d41586-017-06925-2

83. Febbraio MA, Reibe S, Shalapour S, Ooi GJ, Watt MJ, Karin M. Preclinical models for studying NASH-driven HCC: How useful are they? Cell Metab. 2019;29(1):18-26. http://dx.doi.org/10.1016/j. cmet.2018.10.012

84. Farrell G, Schattenberg JM, Leclercq I, Yeh MM, Goldin R, Teoh N, et al. Mouse models of nonalcoholic steatohepatitis: Toward optimization of their relevance to human nonalcoholic steatohepatitis. Hepatology. 2019;69(5):2241-57. http://dx.doi.org/10.1002/hep.30333

85. Corbin $\mathrm{KD}$, Zeisel $\mathrm{SH}$. Choline metabolism provides novel insights into nonalcoholic fatty liver disease and its progression. Curr Opin Gastroen. 2012;28(2):159-65. http://dx.doi.org/10.1097/ MOG.0b013e32834e7b4b

86. Ghoshal AK, Rushmore TH, Farber E. Initiation of carcinogenesis by a dietary deficiency of choline in the absence of added carcinogens. Cancer Lett. 1987;36(3):289-96. http://dx.doi. org/10.1016/0304-3835(87)90022-X

87. da Costa KA, Garner SC, Chang J, Zeisel SH. Effects of prolonged (1 year) choline deficiency and subsequent re-feeding of choline on 1,2-sn-diradylglycerol, fatty acids and protein kinase $C$ in rat liver. Carcinogenesis. 1995;16(2):327-34. http://dx.doi.org/10.1093/carcin/16.2.327

88. Lau JKC, Zhang X, Yu J. Animal models of non-alcoholic fatty liver disease: Current perspectives and recent advances. J Pathology. 2017;241(1):36-44. http://dx.doi.org/10.1002/path.4829

89. Dela Pena A, Leclercq I, Field J, George J, Jones B, Farrell G. NF-kappa B activation, rather than TNF, mediates hepatic inflammation in a murine dietary model of steatohepatitis. Gastroenterology. 2005;129(5):1663-74. http://dx.doi.org/10.1053/j.gastro.2005.09.004

90. Ip E, Farrell G, Hall P, Robertson G, Leclercq I. Administration of the potent PPAR alpha agonist, Wy-14,643, reverses nutritional fibrosis and steatohepatitis in mice. Hepatology. 2004;39(5):128696. http://dx.doi.org/10.1002/hep.20170

91. Raubenheimer PJ, Nyirenda MJ, Walker BR. A choline-deficient diet exacerbates fatty liver but attenuates insulin resistance and glucose intolerance in mice fed a high-fat diet. Diabetes. 2006;55(7):201520. http://dx.doi.org/10.2337/db06-0097

92. Tirnitz-Parker JEE, Viebahn CS, Jalcubowski A, Klopcic BRS, Olynyk JK, Yeoh GCT, et al. Tumor necrosis factor-like weak inducer of apoptosis is a mitogen for liver progenitor cells. Hepatology. 2010;52(1):291-302. http://dx.doi.org/10.1002/hep.23663 
93. Knight B, Tirnitz-Parker JE, Olynyk JK. C-kit inhibition by imatinib mesylate attenuates progenitor cell expansion and inhibits liver tumor formation in mice. Gastroenterology. 2008;135(3):969-79, 79 el. http://dx.doi.org/10.1053/j.gastro.2008.05.077

94. Lau JK, Zhang X, Yu J. Animal models of non-alcoholic fatty liver disease: Current perspectives and recent advances. J Pathol. 2017;241(1):36-44. http://dx.doi.org/10.1002/path.4829

95. Heydemann A. An overview of murine high fat diet as a model for type 2 diabetes mellitus. J Diabetes Res. 2016. http://dx.doi.org/10.1155/2016/2902351

96. Gaemers IC, Stallen JM, Kunne C, Wallner C, van Werven J, Nederveen A, et al. Lipotoxicity and steatohepatitis in an overfed mouse model for non-alcoholic fatty liver disease. Bba-Mol Basis Dis. 2011;1812(4):447-58. http://dx.doi.org/10.1016/j.bbadis.2011.01.003

97. Tetri LH, Basaranoglu M, Brunt EM, Yerian LM, Neuschwander-Tetri BA. Severe NAFLD with hepatic necroinflammatory changes in mice fed trans fats and a high-fructose corn syrup equivalent. Am J Physiol-Gastr L. 2008;295(5):G987-95. http://dx.doi.org/10.1152/ajpgi.90272.2008

98. Dowman JK, Hopkins LJ, Reynolds GM, Nikolaou N, Armstrong MJ, Shaw JC, et al. Development of hepatocellular carcinoma in a murine model of nonalcoholic steatohepatitis induced by use of a high-fat/fructose diet and sedentary lifestyle. Am J Pathol. 2014;184(5):1550-61. http://dx.doi. org/10.1016/j.ajpath.2014.01.034

99. Charlton M, Krishnan A, Viker K, Sanderson S, Cazanave S, McConico A, et al. Fast food diet mouse: Novel small animal model of NASH with ballooning, progressive fibrosis, and high physiological fidelity to the human condition. Am J Physiol Gastrointest Liver Physiol. 2011;301(5):G825-34. http://dx.doi.org/10.1152/ajpgi.00145.2011

100. Asgharpour A, Cazanave SC, Pacana T, Seneshaw M, Vincent R, Banini BA, et al. A diet-induced animal model of non-alcoholic fatty liver disease and hepatocellular cancer. J Hepatol. 2016;65(3):579-88. http://dx.doi.org/10.1016/j.jhep.2016.05.005

101. Tsuchida T, Lee YA, Fujiwara N, Ybanez M, Allen B, Martins S, et al. A simple diet- and chemicalinduced murine NASH model with rapid progression of steatohepatitis, fibrosis and liver cancer. J Hepatol. 2018;69(2):385-95. http://dx.doi.org/10.1016/j.jhep.2018.03.011

102. Nakagawa H, Umemura A, Taniguchi K, Font-Burgada J, Dhar D, Ogata H, et al. ER stress cooperates with hypernutrition to trigger TNF-dependent spontaneous HCC development. Cancer Cell. 2014;26(3):331-43. http://dx.doi.org/10.1016/j.ccr.2014.07.001

103. Kim JY, Garcia-Carbonell R, Yamachika S, Zhao P, Dhar D, Loomba R, et al. ER stress drives lipogenesis and steatohepatitis via caspase-2 activation of S1P. Cell. 2018;175(1):133.http://dx.doi.org/10.1016/j. cell.2018.08.020

104. Niu ZS, Niu XJ, Wang WH. Genetic alterations in hepatocellular carcinoma: An update. World J Gastroentero. 2016;22(41):9069-95. http://dx.doi.org/10.3748/wjg.v22.i41.9069

105. Schulze K, Imbeaud S, Letouze E, Alexandrov LB, Calderaro J, Rebouissou S, et al. Exome sequencing of hepatocellular carcinomas identifies new mutational signatures and potential therapeutic targets. Nat Genet. 2015;47(5):505-U106. http://dx.doi.org/10.1038/ng.3252

106. Cancer Genome Atlas Research Network. Electronic address wbe, Cancer Genome Atlas Research $\mathrm{N}$. Comprehensive and integrative genomic characterization of hepatocellular carcinoma. Cell. 2017;169(7):1327-41 e23.

107. Newell P, Villanueva A, Friedman SL, Koike K, Llovet JM. Experimental models of hepatocellular carcinoma. J Hepatol. 2008;48(5):858-79. http://dx.doi.org/10.1016/j.jhep.2008.01.008

108. Zheng K, Cubero FJ, Nevzorova YA. c-Myc-making liver sick: Role of c-Myc in hepatic cell function, homeostasis and disease. Genes (Basel). 2017;8(4). http://dx.doi.org/10.3390/genes8040123

109. Sandgren EP, Quaife CJ, Pinkert CA, Palmiter RD, Brinster RL. Oncogene-induced liver neoplasia in transgenic mice. Oncogene. 1989;4(6):715-24.

110. Murakami H, Sanderson ND, Nagy P, Marino PA, Merlino G, Thorgeirsson SS. Transgenic mouse model for synergistic effects of nuclear oncogenes and growth factors in tumorigenesis: Interaction of c-Myc and transforming growth factor alpha in hepatic oncogenesis. Cancer Res. 1993;53(8):1719-23.

111. Freimuth J, Gassler N, Moro N, Gunther RW, Trautwein C, Liedtke C, et al. Application of magnetic resonance imaging in transgenic and chemical mouse models of hepatocellular carcinoma. Mol Cancer. 2010;9:94. http://dx.doi.org/10.1186/1476-4598-9-94 
112. Thorgeirsson SS, Santoni-Rugiu E. Transgenic mouse models in carcinogenesis: Interaction of c-Myc with transforming growth factor alpha and hepatocyte growth factor in hepatocarcinogenesis. Br J Clin Pharmacol. 1996;42(1):43-52. http://dx.doi.org/10.1046/j.1365-2125.1996.03748.x

113. Beer S, Komatsubara K, Bellovin DI, Kurobe M, Sylvester K, Felsher DW. Hepatotoxin-induced changes in the adult murine liver promote MYC-induced tumorigenesis. PLoS One. 2008;3(6):e2493. http://dx.doi.org/10.1371/journal.pone.0002493

114. Shachaf CM, Kopelman AM, Arvanitis C, Karlsson A, Beer S, Mandl S, et al. MYC inactivation uncovers pluripotent differentiation and tumour dormancy in hepatocellular cancer. Nature. 2004;431(7012):1112-17. http://dx.doi.org/10.1038/nature03043

115. Farra R, Grassi G, Tonon F, Abrami M, Grassi M, Pozzato G, et al. The role of the transcription factor E2F1 in hepatocellular carcinoma. Curr Drug Deliv. 2017;14(2):272-81.

116. Conner EA, Lemmer ER, Omori M, Wirth PJ, Factor VM, Thorgeirsson SS. Dual functions of E2F-1 in a transgenic mouse model of liver carcinogenesis. Oncogene. 2000;19(44):5054-62. http://dx.doi. org/10.1038/sj.onc. 1203885

117. Conner EA, Lemmer ER, Sanchez A, Factor VM, Thorgeirsson SS. E2F1 blocks and c-Myc accelerates hepatic ploidy in transgenic mouse models. Biochem Biophys Res Commun. 2003;302(1):114-20. http://dx.doi.org/10.1016/S0006-291X(03)00125-6

118. Shirolkar GD, Pasic S, Gogoi-Tiwari J, Bhat MK, Olynyk JK, Dharmarajan A, et al. Wnt/ß-Catenin signalling during liver metabolism, chronic liver disease and hepatocarcinogenesis. J Renal Hepatic Disord. 2018;2(1):1-9. http://dx.doi.org/10.15586/jrenhep.2018.29

119. Zhan T, Rindtorff N, Boutros M. Wnt signaling in cancer. Oncogene. 2017;36(11):1461-73. http:// dx.doi.org/10.1038/onc.2016.304

120. Khalaf AM, Fuentes D, Morshid AI, Burke MR, Kaseb AO, Hassan M, et al. Role of Wnt/beta-catenin signaling in hepatocellular carcinoma, pathogenesis, and clinical significance. J Hepatocell Carcinoma. 2018;5:61-73. http://dx.doi.org/10.2147/JHC.S156701

121. Calvisi DF, Factor VM, Loi R, Thorgeirsson SS. Activation of beta-catenin during hepatocarcinogenesis in transgenic mouse models: Relationship to phenotype and tumor grade. Cancer Res. 2001;61(5):2085-91.

122. Harada N, Miyoshi H, Murai N, Oshima H, Tamai Y, Oshima M, et al. Lack of tumorigenesis in the mouse liver after adenovirus-mediated expression of a dominant stable mutant of beta-catenin. Cancer Res. 2002;62(7):1971-7.

123. Harada N, Oshima H, Katoh M, Tamai Y, Oshima M, Taketo MM. Hepatocarcinogenesis in mice with beta-catenin and Ha-ras gene mutations. Cancer Res. 2004;64(1):48-54. http://dx.doi. org/10.1158/0008-5472.CAN-03-2123

124. Colnot S, Decaens T, Niwa-Kawakita M, Godard C, Hamard G, Kahn A, et al. Liver-targeted disruption of Apc in mice activates beta-catenin signaling and leads to hepatocellular carcinomas. Proc Natl Acad Sci U S A. 2004;101(49):17216-21. http://dx.doi.org/10.1073/pnas.0404761101

125. Senni N, Savall M, Cabrerizo Granados D, Alves-Guerra MC, Sartor C, Lagoutte I, et al. beta-cateninactivated hepatocellular carcinomas are addicted to fatty acids. Gut. 2019;68(2):322-34. http:// dx.doi.org/10.1136/gutjnl-2017-315448

126. Hussain SP, Schwank J, Staib F, Wang XW, Harris CC. TP53 mutations and hepatocellular carcinoma: Insights into the etiology and pathogenesis of liver cancer. Oncogene. 2007;26(15):2166-76. http:// dx.doi.org/10.1038/sj.onc.1210279

127. Dumble ML, Knight B, Quail EA, Yeoh GC. Hepatoblast-like cells populate the adult p53 knockout mouse liver: Evidence for a hyperproliferative maturation-arrested stem cell compartment. Cell Growth Differ. 2001;12(5):223-31.

128. Dumble ML, Croager EJ, Yeoh GC, Quail EA. Generation and characterization of p53 null transformed hepatic progenitor cells: Oval cells give rise to hepatocellular carcinoma. Carcinogenesis. 2002;23(3):435-45. http://dx.doi.org/10.1093/carcin/23.3.435

129. Katz SF, Lechel A, Obenauf AC, Begus-Nahrmann Y, Kraus JM, Hoffmann EM, et al. Disruption of Trp53 in livers of mice induces formation of carcinomas with bilineal differentiation. Gastroenterology. 2012;142(5):1229.http://dx.doi.org/10.1053/j.gastro.2012.02.009

130. Wang L, Wang WL, Zhang Y, Guo SP, Zhang J, Li QL. Epigenetic and genetic alterations of PTEN in hepatocellular carcinoma. Hepatol Res. 2007;37(5):389-96. http://dx.doi. org/10.1111/j.1872-034X.2007.00042.x 
131. Shearn CT, Petersen DR. Understanding the tumor suppressor PTEN in chronic alcoholism and hepatocellular carcinoma. Adv Exp Med Biol. 2015;815:173-84. http://dx.doi. org/10.1007/978-3-319-09614-8_10

132. Horie Y, Suzuki A, Kataoka E, Sasaki T, Hamada K, Sasaki J, et al. Hepatocyte-specific Pten deficiency results in steatohepatitis and hepatocellular carcinomas. J Clin Investig. 2004;113(12):1774-83. http://dx.doi.org/10.1172/JCI20513

133. Galicia VA, He LN, Dang HE, Kanel G, Vendryes C, French BA, et al. Expansion of hepatic tumor progenitor cells in Pten-null Mice requires liver injury and is reversed by loss of AKT2. Gastroenterology. 2010;139(6):2170-82. http://dx.doi.org/10.1053/j.gastro.2010.09.002

134. Walrath JC, Hawes JJ, Van Dyke T, Reilly KM. Genetically engineered mouse models in cancer research. Adv Cancer Res. 2010;106:113-64. http://dx.doi.org/10.1016/S0065-230X(10)06004-5

135. Brown ZJ, Heinrich B, Greten TF. Mouse models of hepatocellular carcinoma: An overview and highlights for immunotherapy research. Nat Rev Gastro Hepat. 2018;15(9):536-54. http://dx.doi. org/10.1038/s41575-018-0033-6

136. Liu F, Song Y, Liu D. Hydrodynamics-based transfection in animals by systemic administration of plasmid DNA. Gene Ther. 1999;6(7):1258-66. http://dx.doi.org/10.1038/sj.gt.3300947

137. Zhang GF, Budker V, Wolff JA. High levels of foreign gene expression in hepatocytes after tail vein injections of naked plasmid DNA. Hum Gene Ther. 1999;10(10):1735-7. http://dx.doi. org/10.1089/10430349950017734

138. Kovacsics D, Raper J. Transient expression of proteins by hydrodynamic gene delivery in mice. Jove-J Vis Exp. 2014(87). http://dx.doi.org/10.3791/51481

139. Zhang G, Gao X, Song YK, Vollmer R, Stolz DB, Gasiorowski JZ, et al. Hydroporation as the mechanism of hydrodynamic delivery. Gene Ther. 2004;11(8):675-82. http://dx.doi.org/10.1038/ sj.gt. 3302210

140. Chen X, Calvisi DF. Hydrodynamic transfection for generation of novel mouse models for liver cancer research. Am J Pathol. 2014;184(4):912-23. http://dx.doi.org/10.1016/j.ajpath.2013.12.002

141. Kobayashi N, Nishikawa M, Hirata K, Takakura Y. Hydrodynamics-based procedure involves transient hyperpermeability in the hepatic cellular membrane: Implication of a nonspecific process in efficient intracellular gene delivery. J Gene Med. 2004;6(5):584-92. http://dx.doi.org/10.1002/ jgm. 541

142. Liu F, Song YK, Liu D. Hydrodynamics-based transfection in animals by systemic administration of plasmid DNA. Gene Ther. 1999;6(7):1258-66. http://dx.doi.org/10.1038/sj.gt.3300947

143. Titchenell PM, Quinn WJ, Lu MJ, Chu QW, Lu WY, Li CH, et al. Direct hepatocyte insulin signaling is required for lipogenesis but is dispensable for the suppression of glucose production. Cell Metabolism. 2016;23(6):1154-66. http://dx.doi.org/10.1016/j.cmet.2016.04.022

144. Villanueva A, Chiang DY, Newell P, Peix J, Thung S, Alsinet C, et al. Pivotal role of mTOR signaling in hepatocellular carcinoma. Gastroenterology. 2008;135(6):1972-83. http://dx.doi.org/10.1053/j. gastro.2008.08.008

145. Sahin F, Kannangai R, Adegbola O, Wang JZ, Su G, Torbenson M. mTOR and P70S6 kinase expression in primary liver neoplasms. Clin Cancer Res. 2004;10(24):8421-5. http://dx.doi.org/10.1158/10780432.CCR-04-0941

146. Zhou LD, Huang Y, Li JD, Wang ZM. The mTOR pathway is associated with the poor prognosis of human hepatocellular carcinoma. Med Oncol. 2010;27(2):255-61. http://dx.doi.org/10.1007/ s12032-009-9201-4

147. Calvisi DF, Wang CM, Ho C, Ladu S, Lee SA, Mattu S, et al. Increased lipogenesis, induced by AKT-mTORCl-RPS6 signaling, promotes development of human hepatocellular carcinoma. Gastroenterology. 2011;140(3):1071-U542. http://dx.doi.org/10.1053/j.gastro.2010.12.006

148. Ho C, Wang C, Mattu S, Destefanis G, Ladu S, Delogu S, et al. AKT (v-akt murine thymoma viral oncogene homolog 1) and N-Ras (neuroblastoma ras viral oncogene homolog) coactivation in the mouse liver promotes rapid carcinogenesis by way of mTOR (mammalian target of rapamycin complex 1), FOXM1 (forkhead box M1)/SKP2, and c-Myc pathways. Hepatology. 2012;55(3):833-45. http:// dx.doi.org/10.1002/hep. 24736

149. Stauffer JK, Scarzello AJ, Andersen JB, De Kluyver RL, Back TC, Weiss JM, et al. Coactivation of AKT and beta-catenin in mice rapidly induces formation of lipogenic liver tumors. Cancer Res. 2011;71(7):2718-27. http://dx.doi.org/10.1158/0008-5472.CAN-10-2705 
150. Carlson CM, Frandsen JL, Kirchhof N, McIvor RS, Largaespada DA. Somatic integration of an oncogene-harboring sleeping beauty transposon models liver tumor development in the mouse. Proc Natl Acad Sci U S A. 2005;102(47):17059-64. http://dx.doi.org/10.1073/pnas.0502974102

151. Ju HL, Ahn SH, Kim DY, Baek S, Chung SI, Seong J, et al. Investigation of oncogenic cooperation in simple liver-specific transgenic mouse models using noninvasive in vivo imaging. PLoS One. 2013;8(3). http://dx.doi.org/10.1371/journal.pone.0059869

152. Hackett PB, Ekker SC, Largaespada DA, McIvor RS. Sleeping beauty transposon-mediated gene therapy for prolonged expression. Adv Genet. 2005;54:189-232. http://dx.doi.org/10.1016/ S0065-2660(05)54009-4

153. Guo Y, Updegraff BL, Park S, Durakoglugil D, Cruz VH, Maddux S, et al. Comprehensive ex vivo transposon mutagenesis identifies genes that promote growth factor independence and leukemogenesis. Cancer Res. 2016;76(4):773-86. http://dx.doi.org/10.1158/0008-5472.CAN-15-1697

154. Yang H, Wang HY, Shivalila CS, Cheng AW, Shi LY, Jaenisch R. One-step generation of mice carrying reporter and conditional alleles by CRISPR/Cas-mediated genome engineering. Cell. 2013;154(6):1370-9. http://dx.doi.org/10.1016/j.cell.2013.08.022

155. Xue W, Chen SD, Yin H, Tammela T, Papagiannakopoulos T, Joshi NS, et al. CRISPR-mediated direct mutation of cancer genes in the mouse liver. Nature. 2014;514(7522):380. http://dx.doi.org/10.1038/ nature 13589

156. Engelholm LH, Riaz A, Serra D, Dagnaes-Hansen F, Johansen JV, Santoni-Rugiu E, et al. CRISPR/ Cas9 engineering of adult mouse liver demonstrates that the Dnajbl-Prkaca gene fusion is sufficient to induce tumors resembling fibrolamellar hepatocellular carcinoma. Gastroenterology. 2017;153(6):1662.http://dx.doi.org/10.1053/j.gastro.2017.09.008

157. Liu YZ, Qi XW, Zeng ZZ, Wang L, Wang J, Zhang T, et al. CRISPR/Cas9-mediated p53 and Pten dual mutation accelerates hepatocarcinogenesis in adult hepatitis B virus transgenic mice. Sci Rep-UK. 2017;7. http://dx.doi.org/10.1038/s41598-017-03070-8

158. Gao MM, Liu DX. CRISPR/Cas9-based Pten knock-out and sleeping beauty transposon-mediated Nras knock-in induces hepatocellular carcinoma and hepatic lipid accumulation in mice. Cancer Biol Ther. 2017;18(7):505-12. http://dx.doi.org/10.1080/15384047.2017.1323597 